OPEN ACCESS

Edited by: Daniela Millan,

Universidad Bernardo O'Higgins,

Chile

Reviewed by:

Changhai Liang,

Dalian University of Technology, China

Hatem Abushammala,

Abu Dhabi University, United Arab

Emirates

*Correspondence:

Saksit Imman

saksit.im@up.ac.th

Specialty section:

This article was submitted to

Green and Sustainable Chemistry,

a section of the journal

Frontiers in Chemistry

Received: 19 April 2021

Accepted: 19 July 2021

Published: 05 August 2021

Citation:

Khongchamnan P, Wanmolee W,

Laosiripojana N, Champreda V,

Suriyachai $N$, Kreetachat $T$, Sakulthaew $C$, Chokejaroenrat $C$ and Imman S (2021) Solvothermal-Based Lignin Fractionation From Corn Stover:

Process Optimization and

Product Characteristics.

Front. Chem. 9:697237.

doi: 10.3389/fchem.2021.697237

\section{Solvothermal-Based Lignin Fractionation From Corn Stover: Process Optimization and Product Characteristics}

\author{
Punjarat Khongchamnan ${ }^{1}$, Wanwitoo Wanmolee ${ }^{2}$, Navadol Laosiripojana ${ }^{3,4}$, \\ Verawat Champreda ${ }^{4}$, Nopparat Suriyachai ${ }^{4,5}$, Torpong Kreetachat ${ }^{1,5}$, \\ Chainarong Sakulthaew ${ }^{6}$, Chanat Chokejaroenrat ${ }^{7}$ and Saksit Imman ${ }^{1,5 *}$
}

${ }^{1}$ School of Energy and Environment, University of Phayao, Muang Phayao, Thailand, ${ }^{2}$ National Nanotechnology Center, National Science and Technology Development Agency, Thailand Science Park, Pathumthani, Thailand, ${ }^{3}$ The Joint Graduate School for Energy and Environment (JGSEE), King Mongkut's University of Technology Thonburi, Bangkok, Thailand, ${ }^{4}$ BIOTEC-JGSEE Integrative Biorefinery Laboratory, National Center for Genetic Engineering and Biotechnology, Pathumthani, Thailand, ${ }^{5}$ Intregated Biorefinery Excellent Center (IBC), School of Energy and Environment, University of Phayao, Muang Phayao, Thailand, ${ }^{6}$ Department of Veterinary Technology, Faculty of Veterinary Technology, Kasetsart University, Bangkok, Thailand, ${ }^{7}$ Department of Environmental Technology and Management, Faculty of Environment, Kasetsart University, Bangkok, Thailand

Fractionation of lignocellulosic is a fundamental step in the production of value-added biobased products. This work proposes an initiative to efficiently extract lignin from the corn stover using a single-step solvothermal fractionation in the presence of an acid promoter $\left(\mathrm{H}_{2} \mathrm{SO}_{4}\right)$. The organic solvent mixture used consists of ethyl acetate, ethanol, and water at a ratio of $30: 25: 45(\mathrm{v} / \mathrm{V})$, respectively. $\mathrm{H}_{2} \mathrm{SO}_{4}$ was utilized as a promoter to improve the performance and selectivity of lignin removal from the solid phase and to increase the amount of recovered lignin in the organic phase. The optimal conditions for this extraction, based on response surface methodology (RSM), are a temperature of $180^{\circ} \mathrm{C}$ maintained for $49.1 \mathrm{~min}$ at an $\mathrm{H}_{2} \mathrm{SO}_{4}$ concentration of $0.08 \mathrm{M}$. The optimal conditions show an efficient reaction with $98.0 \%$ cellulose yield and $75.0 \%$ lignin removal corresponding to $72.9 \%$ lignin recovery. In addition, the extracted lignin fractions, chemical composition, and structural features were investigated using Fourier transform infrared spectroscopy, thermogravimetric analysis, elemental analysis, and twodimensional heteronuclear single quantum coherence nuclear magnetic resonance spectroscopy (2D-HSQC NMR). The results indicate that the recovered lignin primarily contains a $\beta-O-4$ linking motif based on 2D-HSQC spectra. In addition, new C-C inter-unit linkages (i.e., $\beta-\beta$, and $\beta-5$ ) are not formed in the recovered lignin during $\mathrm{H}_{2} \mathrm{SO}_{4}$-catalyzed solvothermal pretreatment. This work facilitates effective valorization of lignin into valueadded chemicals and fuels.

Keywords: corn stover, homogeneous catalyst, lignin fractionation, solvothermal based, optimization, phenolic compound 


\section{INTRODUCTION}

The development of alternative energy sources is important due to the depletion of fossil fuels and increased air pollution created by conventional vehicle combustion (Perera, 2017). Lignocellulosic materials from agricultural residual waste (such as rice straw, corn cob, and corn stover) have immense potential as replacements for fossil fuels and in reducing environmental problems. Several processes for utilizing these sustainable materials have been investigated globally (Ahorsu et al., 2018). Lignocellulosic material comprises mainly 35-50\% cellulose, 20-35\% hemicellulose, and 10-25\% lignin (Kupczyk et al., 2019). Lignintraditionally considered a value-added product obtained during the fractionation process (Schutyser et al., 2018)-is classified as a three-dimensional amorphous polymer, consisting of p-coumaryl alcohol (4-hydroxycinnamyl), coniferyl alcohol (3methoxy 4-hydroxycinnamyl), and sinapyl alcohols or 3,5dimethoxy-4-hydroxycinnamyl (Mathew et al., 2018). The main lignin structure is characterized by various types of crosslinks. These structures are assembled via ether (such as $\beta-\mathrm{O}-4, \alpha-\mathrm{O}-4$, and $4-\mathrm{O}-5$ ) and C-C bonds (Buranov and Mazza, 2008). The main functional groups include aliphatic, hydroxyl, carboxyl, carbonyl, phenolic, and methoxyl groups; the contents of these groups are higher in softwood lignin than in hardwood lignin (More, 2019). Typically, lignin can be combusted as a low-grade fuel to produce heat on an industrial scale. Recently, several studies have attempted to fractionate lignin from the biomass and to obtain high purity lignin-based products.

Fractionation of agricultural residues is a prerequisite for an integrated biorefinery. Thus far, studies have reported on the clean fractionation (CF) process utilizing a ternary organosolvent mixture comprised of an organic solvent, water, and alcohol, in order to establish one-step isolation of the agricultural components with a relative high purity of each fraction. In CF, cellulose is enhanced in the solid pulp, and the hemicellulose-derived products are included in the aqueous phase, while a large amount of pure lignin is found in the organic fraction (Suriyachai et al., 2017). Lignin extracted via the organosolv process is called organosolv lignin. The extraction is called lignin's potential source for depolymerization into beneficial biobased chemical products such as guaiacol, 4methyl-guaiacol, 4-ethyl-guaiacol, 4-vinyl-guaiacol, vanillin, syringol, phenol, 4-methylphenol, 2,5-dimethylphenol, 4-hydroxy2-methoxycinnamaldehyde, catechol, 3-methoxycatechol, toluene, p-xylene, and styrene (Zhang and Wang, 2020). Zhang et al. (2019) studied the fractionation of lignin from corncobs using a solvothermal process to separate the lignin for subsequent depolymerization. The optimal conditions were a temperature of $200^{\circ} \mathrm{C}$ maintained for $1 \mathrm{~h}$ using $\mathrm{H}_{2} \mathrm{O} / \mathrm{n}$-butanol (4:6, v/v). The results indicated that the maximum yields of extracted lignin and phenolic monomers were 87.1 and $19.5 \%$, respectively. Ouyang et al. (2018) reported a two-step catalytic process for coupling the fractionation of woody biomass and the depolymerization of isolated lignin. Among various processes for the acidcatalyzed fractionation of biomass in methanol, the presence of sulfuric acid produced the best performance, with $70 \%$ of delignification. It was found that the degree of delignification impacted the yield in the depolymerization step due to the different repolymerization of lignin fragments. Inkrod et al. (2018) studied the CF of various lignocellulosic materials using a solvent mixture comprising methyl isobutyl ketone (MIBK), ethanol, and water using $\mathrm{H}_{2} \mathrm{SO}_{4}$. It was found that the efficiency of lignin isolation depended on the type of biomass. The separated lignin materials had different levels of purity and physiochemical properties. Meng et al. (2020) investigated the effect of various organosolv processes on the structure of woody biomass. At their optimal conditions, these organosolv processes facilitated the delignification of approximately 84, 85, and $52 \%$ ethanol $(\mathrm{EtOH})$, co-solvent enhanced lignocellulosic fractionation (CELF), and $\gamma$-Valerolactone (GVL), respectively. Further, various organosolv processes produced different quantities of $\beta-\mathrm{O}-4$ linkages. The preservation of these linkages is suitable for depolymerization to mono-aromatic compounds. Imman et al. (2015) studied the single-step solvothermal fractionation of rice straw (RS) with various organic solvents consisting of methyl isobutyl keone, ethyl acetate, toluene and diethyl ether, and acid promoter $\left(\mathrm{H}_{2} \mathrm{SO} 4\right.$, $\mathrm{HCl}$, and $\left.\mathrm{H}_{3} \mathrm{PO} 4\right)$ at $180{ }^{\circ} \mathrm{C}$ for $60 \mathrm{~min}$. The results showed that the optimal conditions were found to be $0.05 \mathrm{M} \mathrm{H}_{2} \mathrm{SO}_{4}$ at $160^{\circ} \mathrm{C}$ for $1 \mathrm{~h}$ with a water/ethanol/ethyl acetate (62.5:25:12.5\%) solvent mixture, resulting in the highest glucan yield of $71.4 \mathrm{wt} \%$, hemicellulose (53.2 wt\%), and lignin recovery (63.1 wt\%) in the organic solvent phase.

Previous studies have shown that the CF process can modify depolymerization to obtain lignin monomers with high selectivity; however, characterization of the extracted lignin from corncob residue is unclear and poorly studied. According to our knowledge, the utilization of single-step solvothermal fractionation using ethyl acetate as an organic solvent under an acid promoter $\left(\mathrm{H}_{2} \mathrm{SO}_{4}\right)$ has not been investigated with regard to extracting fractionated lignin from the corn stover. The use of ethyl acetate completed the drying process for isolated lignin. However, the side hydrolysis of ethyl acetate is required for further process optimization. This work aimed to enhance the yield and purity of separated lignin by solvothermal fractionation. The lignin fractionation process was carried out using ternary mixture solvents. A homogeneous catalyst was used as an acid promoter to enhance the recovery of lignin. Further characterization approaches (Klason lignin determination, elemental analysis, FT-IR, HPLC, TGA, GPC, 2DNMR-HSQC, XRD, BET, SEM, and pyrolysis GC-MS) were applied for a qualitative and quantitative analysis of the separated lignin, and to compare its properties with those of commercial lignin. The sulfuric acid catalyzed solvothermal process developed in this study enables efficient extraction of high-value organosolv lignin from the corn stover and the production of recovered lignin in the organic phase with low contamination by the other contents. The lignin characteristic data contributes to the development of lignin valorization in value-added applications.

\section{MATERIALS AND METHODOLOGY}

\section{Materials}

The corn stover was obtained from Ban so, Phayao, Thailand and dried at $70^{\circ} \mathrm{C}$ for $24 \mathrm{~h}$ in a hot air oven. Afterward, the dried corn 
stover was ground and sieved to a particles size between 0.5 and $2.0 \mathrm{~mm}$. The final moisture content of the milled corn stover was $7 \%$, measured as per the weight loss after drying in an oven $\left(105^{\circ} \mathrm{C}\right)$ to achieve a constant weight within $5 \mathrm{~h}$. For the experiments, the prepared corn stover was kept in sealed plastic bags at room temperature. The chemical composition was determined according to the analytical procedures of the National Renewable Energy Laboratory (Sluiter et al., 2008); dried corn stover was composed of cellulose $(30 \%)$, hemicellulose (18\%), lignin (35\%), ash (10\%), and extractives (7\%). The commercial kraft lignin used in this work was provided by Sigma-Aldrich (low sulfonate content $\sim 4 \%$ and $\mathrm{pH} \sim 10.5$ ) for comparative study.

\section{Procedure of Lignin Isolation From Corn Stover Using Solvothermal Fractionation}

Organosolv fractionation of raw corn stover was implemented in a stainless-steel reactor with a capacity of $600 \mathrm{ml}$. The corn stover was heated using an electric jacket with an inside thermocouple to measure the temperature (Parr Reactor 4,560, Parr Instrument Co., Moline, IL, United States). Initially, the screened corn stover sample $(10 \mathrm{~g})$ was mixed with the single-phase solvent mixture $(100 \mathrm{ml})$ consisting of ethyl acetate: ethanol: water (30:25:45 v/v\%) with various concentrations of $\mathrm{H}_{2} \mathrm{SO}_{4}$ acid promoter (0.05-0.1 M). The temperature and reaction time of each reaction ranged from 140 to $180^{\circ} \mathrm{C}$ and $30-60 \mathrm{~min}$, respectively. The reaction time started once the target temperature had been reached. The heating profiles at different temperatures were provided to enable an understanding of their characteristics under fractionation conditions (Supplementary Figure S1). The reaction nitrogen gas $\left(\mathrm{N}_{2}\right)$ was added in the reactor at a beginning pressure of 20 bar. The reaction was stirred at $100 \mathrm{rpm}$ to maintain a homogeneous system. At the end of the reaction time, a water bath was used to quench the reaction immediately. The solid cellulose-enriched fraction was isolated using filtration and then washed with a mixture of ethyl acetate and $300 \mathrm{ml}$ of water (1:2, $\mathrm{v} / \mathrm{v})$. Next, the liquid fraction was aggregated and settled in a separatory funnel. An appropriate amount of DI water was added to the liquid fraction. The slurry was then incubated at room temperature for $20 \mathrm{~min}$ to reach phase separation. Then, the aqueous phase (water, ethanol, acid promoter, and soluble products) was recovered. The separated organic phase (ethyl acetate) was dried at $105^{\circ} \mathrm{C}$ to obtain the separated lignin. Outputs were measured based on weight. The chemical composition was determined by applying the NREL method. The cellulose yield, cellulose purity, hemicellulose removal, lignin removal, and recovered lignin were calculated using the following equations:

Cellulose yield (\%)

$$
=\frac{(\text { Cellulose remaining in solid pulp }(\mathrm{mg}))}{(\text { Cellulose content in raw corn stover }(\mathrm{mg}))} \times 100
$$

Cellulose purity (\%)

$$
=\frac{(\text { Cellulose remaining in solid pulp }(\mathrm{mg}))}{(\text { Total content in solid pulp }(\mathrm{mg}))} \times 100
$$

Hemicellulose removal $(\%)=$

$\underline{\text { (Hemicellulose content in raw corn stover }(\mathrm{mg}))-(\text { Hemicellulose remaining in solid pulp }(\mathrm{mg}))} \times 100$ (Hemicellulose content in raw corn stover $(\mathrm{mg})$ )

Lignin removal $(\%)=$

$\frac{(\text { Lignin content in raw corn stover }(\mathrm{mg}))-(\text { Lignin remaining in solid pulp }(\mathrm{mg}))}{(\text { Lignin content in raw corn stover }(\mathrm{mg}))} \times 100$

Recovered lignin $(\%)=$

$\frac{\text { (Weight of recovered lignin from organic phase }(\mathrm{mg}))}{(\text { Lignin content in raw corn stover }(\mathrm{mg}))} \times 100$

\section{Statistical Design and Optimization for Recovered Lignin Using Response Surface Methodology}

The experiment design and statistical analysis were implemented following the Box-response surface design method utilizing the Design Expert software (version 10.0.1). The experimental design was explored with three independent factors, based on a BoxBehnken design (BBD) with three levels. The three factors were reaction temperature $\left(\mathrm{X}_{1}, 140-80^{\circ} \mathrm{C}\right)$, reaction time $\left(\mathrm{X}_{2}\right.$, 20-60 min), and acid promoter concentration $\left(\mathrm{X}_{3}\right.$, $0.05-0.1 \mathrm{M})$, with three coded levels for each factor $(-1,0,1)$. Fifteen experiments with three replications at the center point were processed randomly. The assessed variance for individual factors was partitioned into offset, linear, interaction, and quadratic components. All parameters were evaluated utilizing a second-order polynomial equation,

$$
\begin{aligned}
& \boldsymbol{Y}=\boldsymbol{\beta}_{0}+\boldsymbol{\beta}_{1} \boldsymbol{X}_{1}+\boldsymbol{\beta}_{2} \boldsymbol{X}_{2}+\boldsymbol{\beta}_{3} \boldsymbol{X}_{3}+\boldsymbol{\beta}_{12} \boldsymbol{X}_{1} \boldsymbol{X}_{2} \\
& +\boldsymbol{\beta}_{13} \boldsymbol{X}_{1} \boldsymbol{X}_{3}+\boldsymbol{\beta}_{23} \boldsymbol{X}_{2} \boldsymbol{X}_{3}+\boldsymbol{\beta}_{11} \boldsymbol{X}_{1}^{2}+\boldsymbol{\beta}_{22} \boldsymbol{X}_{2}^{2}+\boldsymbol{\beta}_{33} \boldsymbol{X}_{3}^{2}
\end{aligned}
$$

where $Y$ is the predicted response; $X_{1}, X_{2}$, and $X_{3}$ are the independent variables; $\beta_{0}$ is a constant; $\beta_{1}, \beta_{2}$, and $\beta_{3}$ are the linear coefficients; $\beta_{12}, \beta_{13}$, and $\beta_{23}$ are the interaction coefficients; and $\beta_{11}, \beta_{22}$, and $\beta_{33}$ are the quadratic coefficients. The fitted quadratic polynomial was utilized to obtain $3 \mathrm{D}$ surface plots of the correlations between the independent variables and response.

\section{Characterization of Isolated Solid Fraction}

A scanning electron microscopy (SEM; JSM-6301F, JEOL, Japan) was used to examine the microstructure of raw corn stover and the remaining solid under optimal conditions. The electron beam energy was $20 \mathrm{Kv}$. The total surface area of the raw material and solid residues from solvothermal fractionation was determined using the Brunauer-Emmett and Teller (BET) method. Surface area and pore volume of the untreated and treated corn stover were determined using nitrogen adsorption/desorption isotherms in a surface area analyzer (TriStar II 3020, Micromeritics Co., United States). The degassing temperature and time were $30^{\circ} \mathrm{C}$ and $15 \mathrm{~h}$, respectively. The crystallinity degrees of the native and isolated corn stover samples were determined using an X-ray diffraction (XRD) instrument (JDX-3530, JEOL, Japan), in which a $\mathrm{Cu} \mathrm{Ka}$ radiation source was provided at $40 \mathrm{kV}$ and $30 \mathrm{~mA}$. The samples were implemented with a speed of $1 \% \mathrm{~min}$, in a range of $2 \theta=5^{\circ}-40^{\circ}$, and a step size of $0.004^{\circ}$ at room temperature. The 
crystallinity index (CrI) was determined using the following equation:

$$
\text { CrI }=\frac{I_{002}-I_{\text {amorphous }}}{I_{002}} \times 100
$$

where $\mathrm{I}_{002}$ is the intensity of the crystalline portion of the biomass (cellulose) at $2=22.4$ and $\mathrm{I}_{\text {amorphous }}$ is the peak of the amorphous portion, (such as cellulose, hemicellulose and lignin), at $2=18.0$.

\section{Characterization of Lignin Elemental Analysis}

The elemental composition of the recovered lignin was quantified using an elemental analyzer CHNS-628 (LECO, Saint Joseph, MI, United States). Lignin samples were placed in a vacuum evaporator and dried at $60^{\circ} \mathrm{C}, 20$ bars, to eliminate moisture. Afterward, a lignin sample $(0.1 \mathrm{~g})$ was placed in a container and its carbon, hydrogen, and nitrogen contents were measured. Then, for sulfur analysis (to determine the amount of sulfur), a lignin sample $(0.2 \mathrm{~g})$ was put in a ceramic boat furnace and incinerated at $1,350^{\circ} \mathrm{C}$ utilizing a sulfur IR cell.

\section{Fourier Transform Infrared Spectroscopy Analysis}

The chemical structure of the recovered lignin was determined using Fourier transform infrared spectroscopy (FTIR) analysis with a PerkinElmer instrument (Waltham, MA, United States), based on the $\mathrm{KBr}$ pellet method to prepare the samples, and recording the region $4,000-400 \mathrm{~cm}^{-1}$ at $4 \mathrm{~cm}^{-1}$ resolution and 32 scans. The peaks of lignin were compared to the peaks of the standard functional groups.

\section{Thermogravimetric Analysis}

The thermal stability of native and isolated lignin was detected using an instrument (Model TA Q50) from TA Instruments Inc. The specimens were heated at a specific rate $\left(5^{\circ} \mathrm{C} / \mathrm{min}\right)$ under a flow of nitrogen gas $(20-35 \mathrm{ml} / \mathrm{min})$. The specimen's weight was controlled as a function of temperature. The recovered lignin (30-50 mg) was weighed in an aluminum pan and heated from ambient temperature to around $1,000^{\circ} \mathrm{C}$ to determine the total mass loss. The curve of weight loss versus temperature was generated from the recorded values and the derivative was calculated to determine the temperature corresponding to the maximum rate of weight loss.

\section{Gel Permeation Chromatography}

The recovered lignin was analyzed using gel permeation chromatography (GPC) to determine the average molecular weight $\left(M_{w}\right)$ and polydispersity index $\left(M_{w} / M_{n}\right)$. The samples were analyzed on a Jasco instrument equipped with an interface (LC-NetII/ADC) and a UV detector $(254 \mathrm{~nm})$. Lignin was dissolved in tetrahydrofuran (THF) at a concentration of $5 \%$ w/v. The conditions performed using the PolarGel-M 803 column and PolarGel-M guard were a flow rate of $0.5 \mathrm{ml} / \mathrm{min}$ at $40^{\circ} \mathrm{C}$. Polystyrene standards (Sigma-Aldrich) in the range $266-55,000 \mathrm{~g} / \mathrm{mol}$ were utilized for the calibration.

\section{Nuclear Magnetic Resonance Spectroscopy}

The molecular structure of the recovered lignin was characterized using 2D-HSQC NMR (two-dimensional heteronuclear single quantum coherence-nuclear magnetic resonance spectroscopy). Lignin $(0.05 \mathrm{~g})$ was dissolved in DMSO- $d_{6}(0.6 \mathrm{ml})$ and compared with commercial kraft lignin and recovered lignin samples using 2D-HSQC NMR analysis (NMR Bruker-AV500 MHz, Bruker, Germany). The experiment began with the determination of the ${ }^{1} \mathrm{H}$ - and ${ }^{13} \mathrm{C}$-dimensions at $10-0 \mathrm{ppm}$ and $220-5 \mathrm{ppm}$, respectively. Details setup of $2 \mathrm{D}-\mathrm{HSQC}$ NMR conditions was published in our previous paper (Wanmolee et al., 2018; Wanmolee et al., 2021). Briefly, the correlation of ${ }^{1} \mathrm{H}$ and ${ }^{13} \mathrm{C}$ $2 \mathrm{D}$ spectra were recorded at $25^{\circ} \mathrm{C}$ using a $500 \mathrm{MHz}$ spectrometer. A total number of scans of 1,024 points with a $1.5 \mathrm{~s}$ recycle delay and a total of 64 scans at 256 time increments were recorded for ${ }^{1} \mathrm{H}$ and ${ }^{13} \mathrm{C}$ dimensions, respectively. The 2D-HSQC NMR data set was processed with MestreNova software using a $90^{\circ}$ shifted square sine-bell apodization window.

\section{Pyrolysis-Gas Chromatography-Mass Spectrometry}

Pyrolysis-gas chromatography-mass spectrometry (Py-GC-MS) was used to determine the chemical composition of the recovered lignin. Pyrolysis of the recovered lignin was conducted at $500^{\circ} \mathrm{C}$ in an EGA/PY-3030D microfurnace pyrolyzer (Frontier Laboratories Ltd., Fukushima, Japan) connected to a GC 7820A system (Agilent Technologies, Inc., Santa Clara, CA), as well as an Agilent 5,975 mass-selective detector (Electron ionization of $70 \mathrm{eV}$ ). The dimensions of the DB-1701 column were an internal diameter of $30 \mathrm{~m} \times 0.25 \mathrm{~mm}$ with a film thickness of $0.25 \mu \mathrm{m}$ (J\&W Scientific, Folsom, CA). The temperature of the oven was set up to increase at two distinct rates: 1) $20^{\circ} \mathrm{C} \mathrm{min}^{-1}$ (from $50^{\circ} \mathrm{C}\left(1 \mathrm{~min}\right.$ ) to $100^{\circ} \mathrm{C}$ ) and 2 ) $6^{\circ} \mathrm{C} \mathrm{min}$ ming $^{-1}$ (starting from $50^{\circ} \mathrm{C}$ to $280^{\circ} \mathrm{C}$ within $5 \mathrm{~min}$ ). Helium

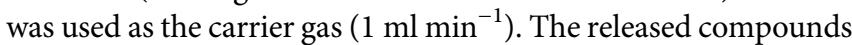
were determined based on a comparison between their mass spectra and 1) those of the Wiley and NIST libraries, 2) the spectra reported in the literature (Zhan et al., 2017), and 3) whenever possible, with the retention times as well as mass spectra of authentic standards. The molar peak areas of the released lignin degradation's individual products were estimated. The summed areas were normalized and the values of two replicates were averaged and presented as a percentage (Wanmolee et al., 2018).

\section{RESULTS AND DISCUSSION}

\section{Effect of Independent Variables on Cellulose Yield, Lignin Removal, and Lignin Recovery}

All responses were evaluated based on the quality and quantity of the remaining solid fraction and the derived products in the 
liquid phase, which were dependent on the levels of independent factors in the solvothermal fractionation process. The optimized conditions were studied using RSM to determine the cellulose yield, hemicellulose removal, lignin removal, and recovered lignin.

Based on the design of the 15 experiments (Table 1), the results indicated that the aforementioned elements varied after the fractionation process in the ranges 74.5-97.3\% (cellulose yield), 78.2-99.3\% (hemicellulose removal), 52.5-76.1\% (lignin removal), and $48.9-72.1 \%$ (recovered lignin). Increased reaction parameters (temperature, time, and acid concentration) led to increasing hemicellulose and lignin removal from the native corn stover into the liquid fraction, whereas the cellulose yield in the remaining solid decreased under severe conditions. The solid recovery was in range $40.9-70.2 \%$ based on weight. The cellulose purity in the solid fraction was in the range 52.9-60.1\% (data not shown). The experiments were performed under optimal conditions to provide detailed information regarding the multiple variables identified based on their greatest effect on fractionation performance. The impact of reaction variables on the major components of the corn stover were determined using the Design Expert software.

The optimization of the solvothermal fractionation conditions was determined for ranges in temperature $\left(140-180^{\circ} \mathrm{C}\right)$, time $(20$ and $60 \mathrm{~min})$, and acid concentration $(0.05-0.1 \mathrm{M})$. All variable options were considered to maximize the responses of cellulose yield, lignin removal, and recovered lignin. The evaluation was analyzed based on the obtained results after the fractionation process (Table 1). The evaluated regression equations for the optimization of solvothermal fractionation considered the cellulose yield $\left(\mathrm{Y}_{1}, \%\right)$, lignin removal $\left(\mathrm{Y}_{2}, \%\right)$, and recovered lignin $\left(\mathrm{Y}_{3}, \%\right)$ as functions of temperature $\left(\mathrm{X}_{1}\right)$, time $\left(\mathrm{X}_{2}\right)$, and acid concentration $\left(\mathrm{X}_{3}\right)$. The predicted equation was fitted to a multiple second-order polynomial regression, defined by Eqs 1-3.

$$
\begin{aligned}
& \text { Cellulose yield }(\%)= \\
& \begin{aligned}
\mathrm{Y}_{1}= & (-128.8)+\left(2.854 \mathrm{X}_{1}\right)-\left(2.883 \mathrm{X}_{2}\right)+\left(1448 \mathrm{X}_{3}\right) \\
& -\left(0.00930 \mathrm{X}_{1}^{2}\right)+\left(0.00943 \mathrm{X}_{3}^{2}\right)-\left(2272 \mathrm{X}_{3}^{2}\right) \\
& +\left(0.012000 \mathrm{X}_{1} \mathrm{X}_{2}\right)-\left(6.180 \mathrm{X}_{1} \mathrm{X}_{3}\right)-\left(1.300 \mathrm{X}_{2} \mathrm{X}_{3}\right)
\end{aligned}
\end{aligned}
$$

Lignin removal $(\%)=$

$$
\begin{aligned}
Y_{2}= & (-19.0)+\left(0.052 X_{1}\right)+\left(2.0304 X_{2}\right)+\left(453 X_{3}\right) \\
& +\left(0.000537 X_{1}^{2}\right)-\left(0.019850 X_{2}^{2}\right)-\left(01976 X_{3}^{2}\right) \\
& -\left(0.000812 X_{1} X_{2}\right)-\left(0.140 X_{1} X_{3}\right)-\left(2.450 X_{2} X_{3}\right)
\end{aligned}
$$

Recovered lignin (\%) =

$$
\begin{aligned}
Y_{3}= & (-86.1)+\left(0.632 X_{1}\right)+\left(2.561 X_{2}\right)+\left(856 X_{3}\right) \\
& +\left(0.000931 X_{1}^{2}\right)-\left(0.021369 X_{2}^{2}\right)-\left(3124 X_{3}^{2}\right) \\
& -\left(0.001325 X_{1} X_{2}\right)-\left(1.550 X_{1} X_{3}\right)-\left(3.000 X_{2} X_{3}\right)
\end{aligned}
$$

As per the analysis of the variance (ANOVA) of the quadratic regression model, equations for the cellulose yield, lignin removal, and recovered lignin responses were statistically significant for the optimized fractionation of the corn stover at the confidence interval of $95 \%$. Additionally, the R-squared values of all responses were greater than 0.9 , which indicated a high level of accuracy of the regression model based on the comparison of the predicted and observed values. The prediction accuracy levels for the cellulose yield, lignin removal, and recovered lignin were 98.57, 99.21, and 99.13\%, respectively. The effects of various parameters on the responses were also investigated. The details and discussions of the parameters for the three main responses (cellulose yield, lignin removal, and lignin yield) are provided in the next section.

Interactive effects of the variables (temperature, time, and acid concentration) on the cellulose yield from the corn stover were determined. The content of cellulose was directly dependent on the levels of various parameters (Figure 1A). The model was considered reliable based on the $p$-value at the $95 \%$ confidence level, with the $p$-value $<0.05$. The linear terms (temperature, time, and acid concentration), quadratic terms (temperature and time), and interaction terms (temperature ${ }^{\star}$ time and temperature ${ }^{*}$ concentration) all had significant effects on the cellulose yield ( $p$-values $<0.05)$. Moreover, the relative coefficient of the sum of squares was summarized to determine the more important corresponding variable as shown in Supplementary Table S1. It was found that the reaction time had the most significant effect (highest coefficient value) on the cellulose yield.

In a previous report, the solvothermal fractionation cellulose yields of $50-60 \%$ were obtained at a high temperature of $180^{\circ} \mathrm{C}$ and a high ethanol concentration of $70 \%$ (Yedro et al., 2015). Harsh conditions, including high temperature, longer reaction time, and high acid concentration, result in the production of byproducts such as furfural, HMF, and other derivative compounds (Nopparat et al., 2018). The formation of the derivative compounds (furfural and HMF) critically decreased the high performance of the subsequent hydrolysis and fermentation steps (Kim, 2018). Further study of the product profiles in aqueous fraction is needed for valorization as coproducts in the fractionation process.

The interactive effects of the variables (temperature, time, and acid concentration) on lignin removal from the corn stover were determined (Figure 1B). Lignin removal was dependent on the values of the parameters. The model was based on the $p$-value at a confidence interval of $95 \%$. It was observed that the linear terms (temperature and time) and quadratic terms (time) both have a significant effect on lignin removal ( $p$-value $<0.05)$. For example, the optimum condition (Run 8 ) had lignin removal of $76.1 \%$, which was more efficient than that observed in a previous study (Hyväkkö et al., 2020). This phenomenon could have been due to a lower pretreatment temperature as well as a shorter exposure time. Lignin removal of $80.3 \%$ from sugarcane bagasse was examined during the pretreatment of ethanol organosolv at $160^{\circ} \mathrm{C}$ for $80 \mathrm{~min}$ ( $\mathrm{Li}$ et al., 2018). Likewise, lignin (77.7\%) was removed from the corn stover during the pretreatment of aqueous ammonia and hot water at $150^{\circ} \mathrm{C}$ for $60 \mathrm{~min}$ (Park et al., 2018). In this research, lignin decomposition was notably decreased under a combination of a relatively lower temperature and a short pretreatment time. 
TABLE 1 | Effect of reaction factors on solid composition of solvothermal fractionation for lignin extraction using the response surface method (RSM).

\begin{tabular}{|c|c|c|c|c|c|c|c|}
\hline \multirow[b]{2}{*}{ Run no. } & \multirow[b]{2}{*}{ Temp ( $\left.{ }^{\circ} \mathbf{C}\right)$} & \multirow{2}{*}{$\frac{\text { Factors }}{\text { Time (min) }}$} & \multirow[b]{2}{*}{ Concentration (M) } & \multicolumn{4}{|c|}{ Responses (\%) } \\
\hline & & & & Cellulose yield $(\%)^{a}$ & Hemicellulose removal (\%) & Lignin removal $(\%)^{b}$ & Recovered lignin $(\%)^{c}$ \\
\hline 1 & 140 & 20 & 0.075 & 97.3 & 78.25 & 52.50 & 49.40 \\
\hline 2 & 180 & 20 & 0.075 & 84.0 & 98.96 & 59.60 & 56.10 \\
\hline 3 & 140 & 60 & 0.075 & 74.5 & 89.93 & 70.0 & 67.12 \\
\hline 4 & 180 & 60 & 0.075 & 80.4 & 99.12 & 75.80 & 71.70 \\
\hline 5 & 140 & 40 & 0.050 & 76.2 & 76.02 & 66.10 & 63.00 \\
\hline 6 & 180 & 40 & 0.050 & 77.6 & 97.22 & 74.30 & 72.10 \\
\hline 7 & 140 & 40 & 0.100 & 86.3 & 89.94 & 68.20 & 64.80 \\
\hline 8 & 180 & 40 & 0.100 & 75.3 & 99.10 & 76.12 & 70.80 \\
\hline 9 & 160 & 20 & 0.050 & 90.0 & 82.27 & 53.30 & 48.90 \\
\hline 10 & 160 & 60 & 0.050 & 80.0 & 89.16 & 71.10 & 68.40 \\
\hline 11 & 160 & 20 & 0.100 & 94.0 & 91.57 & 57.40 & 53.60 \\
\hline 12 & 160 & 60 & 0.100 & 81.4 & 99.37 & 70.30 & 67.10 \\
\hline 13 & 160 & 40 & 0.075 & 84 & 92.04 & 72.20 & 70.00 \\
\hline 14 & 160 & 40 & 0.075 & 84 & 92.04 & 72.20 & 70.00 \\
\hline 15 & 160 & 40 & 0.075 & 84 & 92.04 & 72.20 & 70.00 \\
\hline
\end{tabular}

${ }^{a}$ Based on relative content of cellulose in remaining pulp.

${ }^{b}$ Based on relative content of lignin in solid pulp compared with lignin content in raw material.

${ }^{c}$ Based on the weight of lignin in organic phase.

Efficient lignin recovery from lignocellulosic biomass using the organosolv process is a promising strategy in biorefining, since the organosolv lignin has high purity and can be modified to produce highly valuable products. In this study, the trend of recovered lignin initially depended on the percentage of lignin removal. This result indicates that harsh conditions can enhance the amount of recovered lignin (Figure 1C). Considering the influence of the parameters on recovered lignin, the model was based on the $p$-value at the confidence interval of $95 \%$. The linear terms (temperature and time) and quadratic terms (time and concentration) both had substantial effects on lignin recovery ( $p$-value $<0.05)$.

\section{Optimization of Reaction Parameters}

According to the model equations for all target responses (Eqs. 4-6), the reaction parameters were optimized based on the final regression model to maximize the individual response. The highest cellulose yield of $100 \%$ was predicted at $140 \underline{\mathrm{o}} \mathrm{C}$ for $20 \mathrm{~min}$ in the presence of $0.05 \mathrm{M}$ acid. Harsher parameters were needed to maximize lignin removal and recovered lignin. The highest lignin removal $(77.9 \%)$ was predicted at $180 \underline{0} \mathrm{C}$ for $49.5 \mathrm{~min}$ with $0.08 \mathrm{M}$ acid promoter. Similar conditions at $180 \underline{\mathrm{o} C}$ for $49.5 \mathrm{~min}$ with $0.07 \mathrm{M}$ acid were required for maximum recovered lignin (74.81\%).

The optimal conditions were prioritized corresponding to the subsequent criteria: cellulose yield $>80 \%$, lignin removal $>70 \%$, and lignin recovery $>70 \%$. These conditions are of practical value in solvothermal fractionation to produce a large yield of cellulose while still achieving good lignin removal and lignin recovery in the organic phases. The regression model analysis indicated that the optimal predicted conditions to meet the particular requirements were $180 \underline{\mathrm{o}} \mathrm{C}$ for $49.1 \mathrm{~min}$ with $0.08 \mathrm{M}$ acid concentration in the solvent mixture of ethyl acetate: ethanol: water (30:25:45 v/v \%). Accordingly, the experimental result obtained under these conditions generated a reaction efficiency of cellulose yield (98.0\%), lignin removal (75.0\%), and recovered lignin $(72.9 \%)$. The experimental results were achieved using the criteria under the optimal conditions, thus verifying the accuracy of the model equations. Previous research studies have shown the maximum yields of recovered lignin in $\mathrm{CF}$ using various lignin solvents and different acid catalysts for fractionation of different lignocellulosic biomass, resulting in high reactivity and selectivity as shown in Supplementary Table S2 (Brudecki et al., 2013; Wen et al., 2013; Cheiwpanich et al., 2017; Nopparat et al., 2017).

\section{Characterization of Native Corn Stover and Remaining Solid After Solvothermal Fractionation Process}

The physiochemical properties of the isolated solid after the solvothermal fractionation under the optimal conditions were compared with that of the native corn stover using several techniques (SEM, BET, and XRD).

The morphological appearance of the solid pulp is shown in Figure 2. The native corn stover was covered with wax and had a smooth, intact surface corresponding to the material's highly ordered, intact structure. In addition, the isolated solid residue after solvothermal fractionation was considerably different from the native corn stover. The fractionation process resulted in the disruption of the surface and microstructure of the native corn stover. This disruption can be attributed to the elimination of waxy surface materials and the related hemicellulose, and lignin. As a result, very pure cellulose fibers were found in the isolated solid fraction, being obtained under the optimal conditions.

Additionally, the crystallinity of the solid fraction was examined using XRD (Figure 3). More decreased crystallinity (61.70\%, based on the CrI) was detected in the isolated solid after solvothermal fractionation than in the native corn stover (76.13\%). Crystallinity can decrease due to the elimination of amorphous hemicellulose and lignin from the biomass in the fractionation process. Furthermore, the harsh conditions can induce decrystallization of the cellulose fraction into an amorphous form, resulting in a substantial decrease in the CrI of the solid sample. 

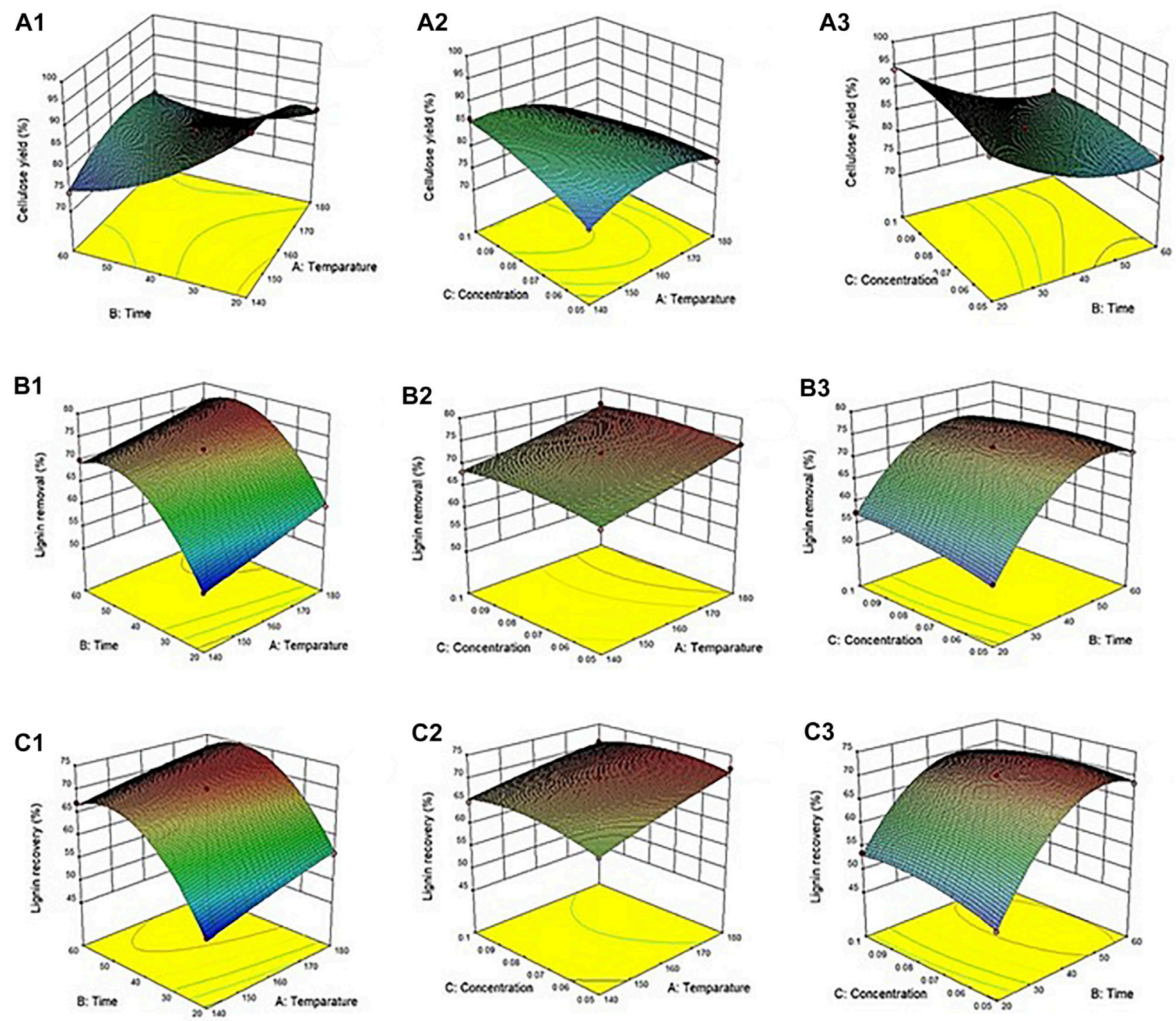

FIGURE 1 | Response surface plot of the solvothermal fractionation process: Effect of various parameters on (A) cellulose yield (B) lignin removal and (C) recovered lignin.

The structural modifications were further characterized using BET analysis (Supplementary Table S3). The solvothermal fractionation induced an expansion in the accessible surface area of the remaining pulp compared with the native corn stover. Substantial increases in the accessible surface area $\left(2.21-7.32 \mathrm{~m}^{2} / \mathrm{g}\right)$ were observed after the fractionation reaction.

\section{Characterization of Lignin Fraction}

The physiochemical properties of lignin recovered from solvothermal fractionation using the optimal conditions were compared to those of commercial kraft lignin using several techniques (FTIR, GPC, TGA, CHONS, proximate analysis, 2DHSQC-NMR, Py-GCMS, SEM, BET, and XRD). The composition of recovered lignin has been characterized previously to study the purity of Klason lignin. It was found that lignin recovered under the optimal conditions $\left(180^{\circ} \mathrm{C}\right.$, $40 \mathrm{~min}$, and $0.075 \mathrm{M}$ acid) consisted of $89.6 \%$ Klason lignin and $0.76 \%$ acid-soluble lignin. Cross-contamination levels with sugar (less than $1.0 \%)$ and ash $(0.16 \%)$ were minimal under these experimental conditions.

\section{Fourier Transform Infrared Spectroscopic Analysis of Commercial Kraft Lignin and Recovered Lignin}

The chemical properties of the recovered lignin in the ethyl acetate phase using the optimal conditions were compared with those of commercial kraft lignin. The results of the FTIR analysis of the recovered lignin and commercial lignin are provided in Table 2; Figure 4. The extracted and commercial 

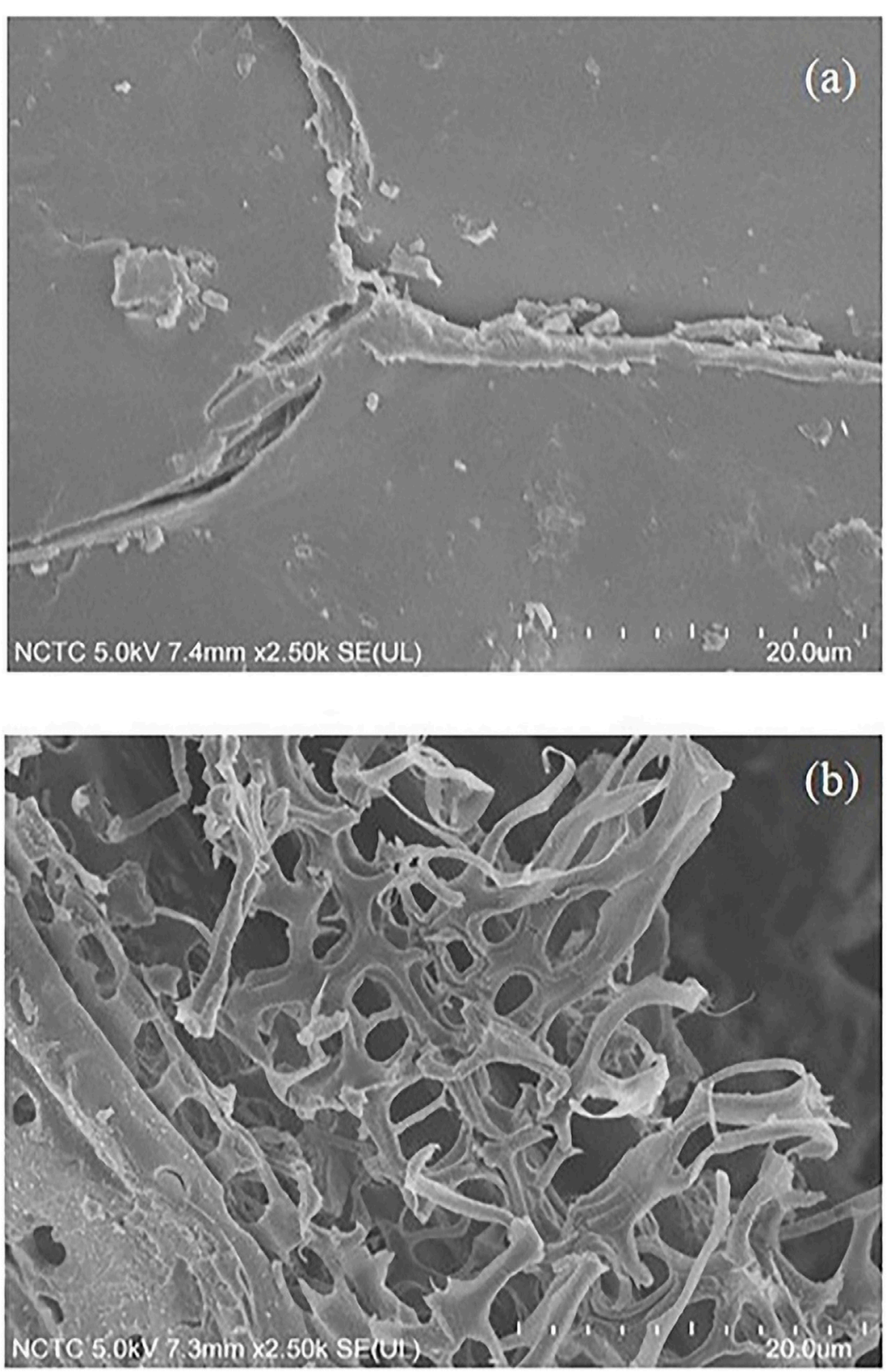

FIGURE 2 | Scanning electron microscopy images of (A) native corn stover and (B) cellulose obtained after the solvothermal fractionation process under the optimal conditions at $0.075 \mathrm{M}$ acid, $180^{\circ} \mathrm{C}$, and $40 \mathrm{~min}$.

lignin were both characterized by the vibration of a hydroxyl group $(\mathrm{O}-\mathrm{H})$ of phenolic and aliphatic compounds at 3,290 and $3,334 \mathrm{~cm}^{-1}$ (Gonultas and Candan, 2018). The vibrations at 2,930 and $2,935 \mathrm{~cm}^{-1}$ were associated with $\left(\mathrm{C}-\mathrm{H}_{2}\right.$ and $\left.\mathrm{C}-\mathrm{H}_{3}\right)$ vibrations in the aromatic methoxyl as well as in the methylene groups of side chains (Balan et al., 2019). The absorbance at $1,688 \mathrm{~cm}^{-1}$ corresponded to a carbonyl/carboxyl group. Variable peak intensity was observed in both samples at $1,422 \mathrm{~cm}^{-1}$ corresponding to the aromatic ring vibrations of a $\mathrm{C}-\mathrm{H}$ group (Bykov, 2008). The intensity at $1,455 \mathrm{~cm}^{-1}$ was related to $\mathrm{CH}_{3}$ in an acetyl group, while the peak at 1,507 was assigned to the aromatic ring $\mathrm{C}=\mathrm{C}$ stretching in lignin (Gonultas and Candan, 2018). The signal at $1,595 \mathrm{~cm}^{-1}$ corresponded to the quantity of the phenyl-propane skeleton present in the samples (DominguezRobles et al., 2017). The vibrations at $1,121-1,213 \mathrm{~cm}^{-1}$ corresponded to the $\mathrm{C}-\mathrm{O}$ stretching of the syringyl (S) and guaiacyl (G) units (Quoc Lam et al., 2001). The peaks at 1,030 and $1,031 \mathrm{~cm}^{-1}$ were associated with the $\mathrm{C}-\mathrm{O}$ vibrations (Oliveira et al., 2009). C-O deformation of the primary alcohols and $\mathrm{C}-\mathrm{H}$ stretching (unconjugated) can also be observed (Klein et al., 


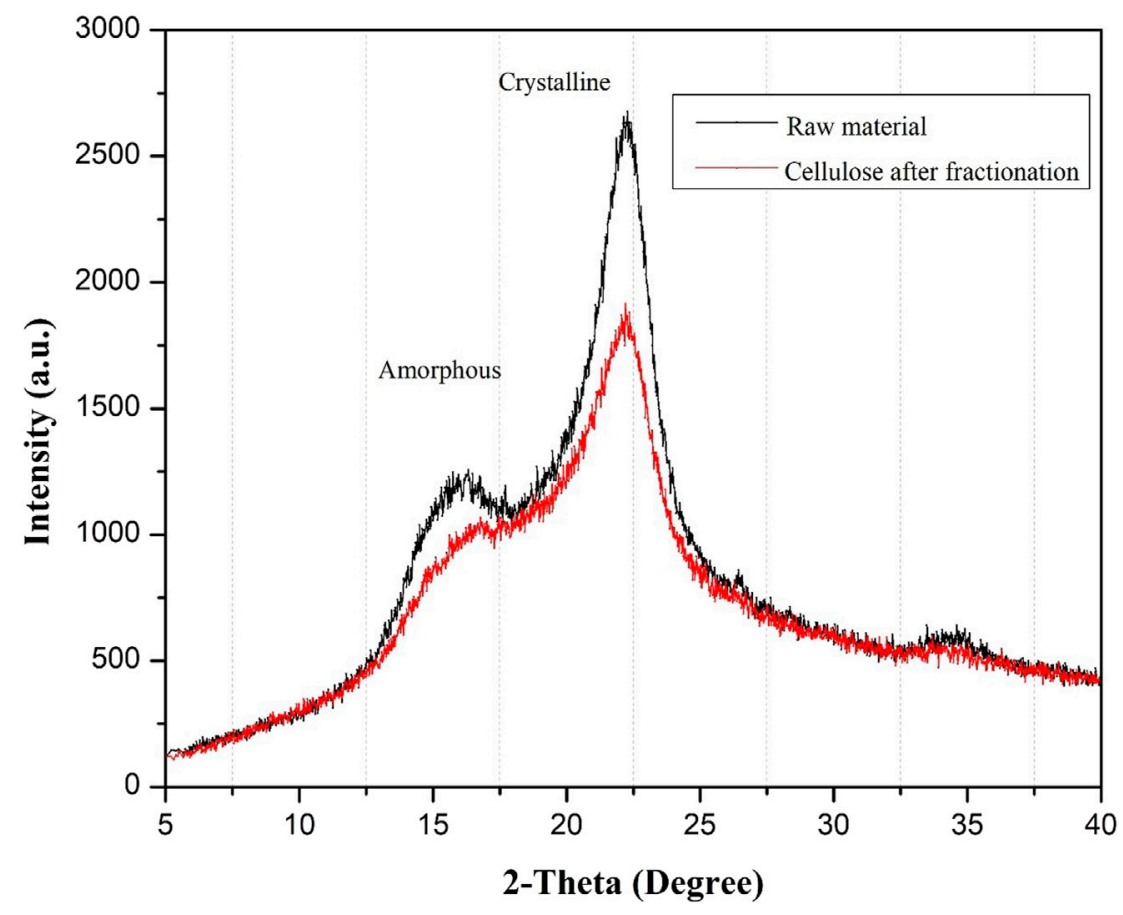

FIGURE 3 | X-ray diffraction patterns of solid residue.

TABLE 2 | The relative functional groups based on FTIR analysis of commercial kraft lignin and recovered lignin obtained from solvothermal fractionation process under the optimal conditions.

\begin{tabular}{|c|c|c|c|c|c|}
\hline Order & $\begin{array}{c}\text { Commercial } \\
\text { kraft } \\
\text { lignin }\end{array}$ & Recovered lignin & Bond & $\begin{array}{l}\text { Wavenumber, } \\
\quad\left(\mathrm{cm}^{-} 1\right)\end{array}$ & Functional group \\
\hline 1 & 3,334 & 3,290 & $\mathrm{O}-\mathrm{H}$ stretch & $3,500-3,200$ & Alcohol, phenol \\
\hline 2 & 2,935 & 2,930 & C-H stretch & $3,000-2,930$ & $\mathrm{C}-\mathrm{H}$ stretch in methyl and methylene groups \\
\hline 3 & 1,688 & 1,688 & $\mathrm{C}=\mathrm{O}$ & $1760-1,665$ & Carbonyl \\
\hline 4 & 1,595 & 1,595 & C-C stretch (in-ring) & $1,605-1,593$ & Aromatic skeleton vibrations (S, G) and C-O stretching \\
\hline 5 & 1,507 & 1,507 & $\mathrm{C}=\mathrm{C}$ stretching & $1,550-1,475$ & Aromatic \\
\hline 6 & 1,422 & 1,422 & $\begin{array}{l}\mathrm{C}-\mathrm{H} \text { in plane deformation } \\
(\mathrm{G}, \mathrm{S})\end{array}$ & $1,430-1,422$ & Aromatics \\
\hline 7 & 1,455 & 1,455 & $\mathrm{C}-\mathrm{H}$ deformation (lignin) & $1,470-1,370$ & Aromatics \\
\hline 8 & $\begin{array}{l}1,213,1,123 \\
1,327\end{array}$ & $\begin{array}{c}1,327,1,213,1,168 \\
1,121\end{array}$ & C-O stretch & $1,320-1,000$ & Alcohol, carboxylic acid, ester, ether \\
\hline 9 & 1,030 & 1,031 & $\mathrm{C}-\mathrm{O}$ vibrations & $1,030.1031$ & $\begin{array}{l}\mathrm{C}-\mathrm{O} \text { deformation in primary alcohols, } \mathrm{C}-\mathrm{H} \text { stretching } \\
\text { (unconjugated) }\end{array}$ \\
\hline 10 & 833 & 832 & $\mathrm{C}-\mathrm{H}$ & $832-817$ & C-H out of plane (G-units) \\
\hline
\end{tabular}

2018). In addition, the absorbance bands at $832-833 \mathrm{~cm}^{-1}$ were associated with the outcome of plane $\mathrm{C}-\mathrm{H}$ vibrations of the guaiacyl units (G) (Raspolli Galletti et al., 2015).

\section{Molecular Weight Distribution of Commercial Kraft Lignin and Recovered Lignin}

The molecular weight distribution of the lignin samples is demonstrated in Table 3. GPC analysis was used to evaluate the average molecular weight $\left(\mathrm{M}_{\mathrm{w}}\right)$, number-average molecular weight $\left(\mathrm{M}_{\mathrm{n}}\right)$, and polydispersity index (PDI) of the recovered lignin and these were compared with those of commercial kraft lignin. The average $M_{w}$ and $M_{n}$ values of the recovered lignin were 1,561 and $1,315 \mathrm{Da}$, respectively, with a PDI of 1.18 . The results indicated that the particle size of the recovered lignin was not influenced by the fractionation process. In comparison, the average $\mathrm{M}_{\mathrm{w}}$ and $\mathrm{M}_{\mathrm{n}}$ values of commercial kraft lignin were 1,399 and 1,046 Da, respectively, with a PDI of 1.34. The commercial lignin had a higher distribution of molecular weight than the recovered lignin. A previous report demonstrated that lignin 


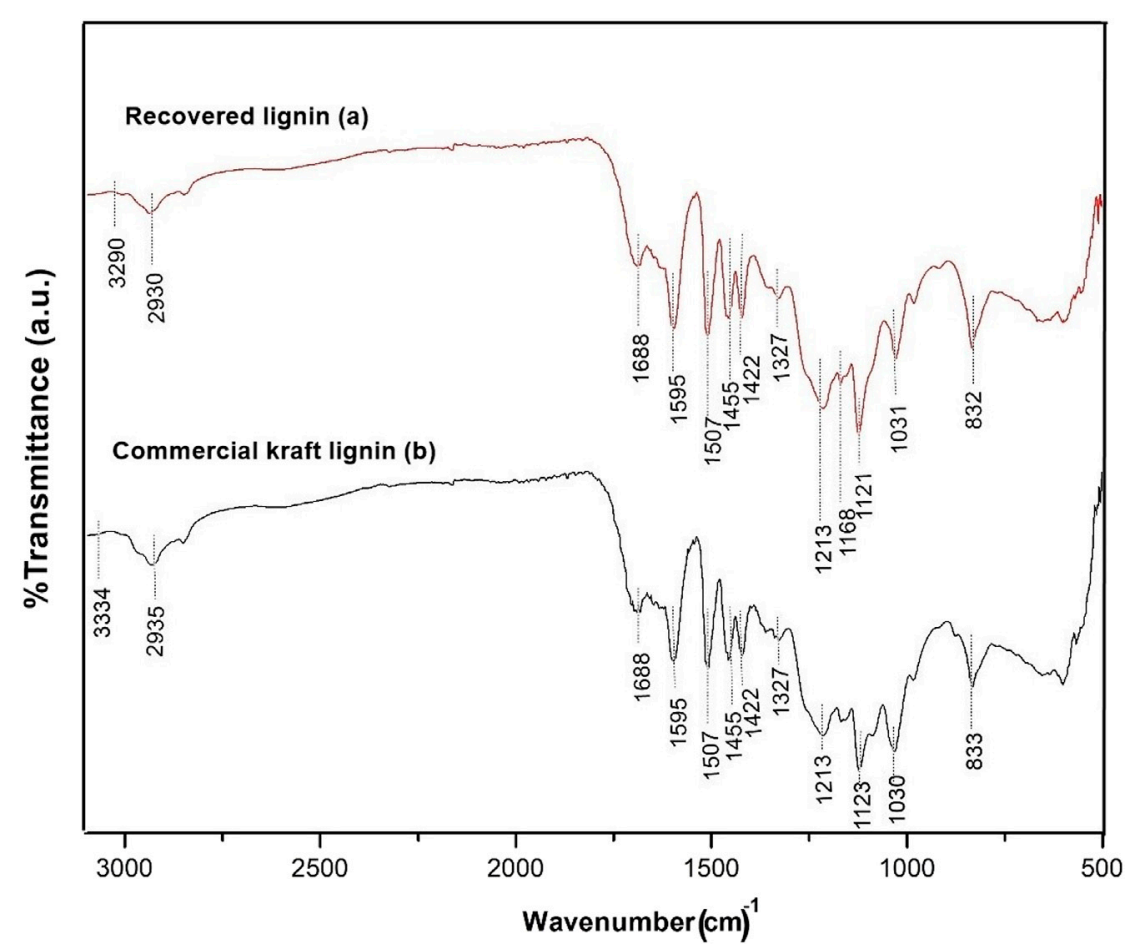

FIGURE 4 | FTIR spectra of (A) recovered lignin and (B) commercial kraft lignin.

\begin{tabular}{|c|c|c|c|c|}
\hline Order & Sample name & $M w^{a}(g / m o l)$ & $M n^{b}(g / m o l)$ & $M w / M n(P D I)^{c}$ \\
\hline 1 & Commercial kraft lignin & 1,399 & 1,046 & 1.34 \\
\hline 2 & Recovered lignin & 1,561 & 1,315 & 1.18 \\
\hline
\end{tabular}

${ }^{a}$ Weight-average molecular weight ( $\left.M w\right)$.

${ }^{b}$ Number-average molecular weight $(\mathrm{Mn})$.

${ }^{c}$ Polydispersity index (PDI).

recovered from BioChoice Lignin (BCL) via the organosolv fractionation process using a ternary mixture (ethyl acetate, 1:1 ethyl acetate/petroleum ether, petroleum ether) had a PDI of 1.12, similar to the PDI of the lignin recovered from the organic phase, which was not significantly different from the PDI of the original lignin (3.33) (Jiang et al., 2016). The recovered lignin obtained under the optimal conditions using the solvothermal conversion process in a previous report had a PDI of 1.66, which was lower than that of commercial lignin (2.39) (Liu et al., 2019). Unlike high molecular weight lignin, low molecular weight lignin can be easily utilized in biochemical and other value-added products in the biorefinery industry (Zhang et al., 2020).

\section{Proximate Analysis of Commercial Kraft Lignin and Recovered Lignin}

The composition of the recovered lignin under the optimal conditions was characterized based on proximate analysis and compared to the commercial kraft lignin (Table 4). The composition of the samples included volatile materials (VM), fixed carbon (FC), moisture, and ash (wt\%, on a dry basis or d.b $\%)$. The recovered lignin and commercial kraft lignin had the same range of elemental contents. The proximate analysis of recovered lignin indicated high contents of volatile matter (61.2-67.6 wt\%), fixed carbon (24.5-35.7 wt\%), moisture $(0.8-2.0 \mathrm{wt} \%)$, and ash (1.0-7.0 wt\%). The ash content in the recovered lignin was slightly higher than that in the commercial kraft lignin apparently because of the high amounts of sulfur used as a promoter in the solvothermal fractionation process (Javad et al., 2014).

\section{Thermal Decomposition of Commercial Kraft Lignin and Recovered Lignin}

Thermogravimetric analysis (TGA) or thermal stability is important in the examination of the thermal properties of the 
TABLE 4 | Proximate and elemental analysis of the commercial kraft lignin and recovered lignin.

\begin{tabular}{|c|c|c|c|c|c|c|c|c|c|}
\hline \multicolumn{4}{|c|}{ Proximate analysis $^{\mathrm{a}}(\%)$} & \multicolumn{6}{|c|}{ Elemental analysis $^{\mathrm{a}}(\%)$} \\
\hline $\begin{array}{l}\text { Commercial kraft } \\
\text { lignin }\end{array}$ & 61.21 & 35.68 & 2.02 & 1.00 & 61.43 & 5.61 & 0.81 & 30.99 & 0.15 \\
\hline Recovered lignin & 67.60 & 24.56 & 0.84 & 7.00 & 63.08 & 5.20 & 0.70 & 30.62 & 0.54 \\
\hline
\end{tabular}

${ }^{a}$ Dry basis (db, wt\%).

recovered lignin and commercial kraft lignin samples as it can identify potential relationships between degradation and chemical structure. The thermal stability levels of the recovered and commercial lignin were assayed using thermogravimetry (TG) and differential thermogravimetry (DTG), as shown in Figure 5. Overall, the degradation of the recovered lignin was divided into four stages. The first stage was observed at $\sim 106.7^{\circ} \mathrm{C}$, considered the dehydration process. In fact, the water content in the recovered lignin is eliminated at temperatures above $100^{\circ} \mathrm{C}$, indicating a strong interaction between the water molecules and hydroxyl groups. The second stage included the decomposition of a number of volatile substances, such as $\mathrm{CO}, \mathrm{CO}_{2}$, and $\mathrm{CH}_{4}$, due to the breaking of the side chains concomitant to a temperature increase from 150 to $350^{\circ} \mathrm{C}$ (Abdelkhalik et al., 2018). The highest lignin decomposition temperatures of recovered and commercial kraft lignin were estimated to be 224 and $318^{\circ} \mathrm{C}$, respectively, due to the breakdown of interunit links and breaking of various bonds of weak internal linkages in the phenolic and organic products during the temperature considering the high content of $\mathrm{b}^{\prime}-\mathrm{O}-4^{\prime}$ linkages (Satari et al., 2019). According to the degradation in the second stage, the weight loss of commercial kraft lignin was approximately $41 \%$ and that of recovered lignin was approximately $46 \%$. This result indicates the higher thermal stability of commercial kraft lignin. The third stage was decomposition above $400^{\circ} \mathrm{C}$, mainly due to the degradation of aromatic rings and breaking of the $\mathrm{C}-\mathrm{C}$ linkages, majorly the $5-5^{\prime}$ and $b^{\prime}-b^{\prime}$ linkages (Gao et al., 2018). Finally, the degradation of the aromatic rings in the demethoxylation reaction (methoxy groups) was observed at temperatures ranging from 450 to $550^{\circ} \mathrm{C}$ (Kawamoto, 2017). This degradation process involves fragmentation of the interunit linkages and release of the monomers and derivatives of the aromatic compounds into the vapor phase. In addition, the weight loss rate of lignin samples is demonstrated in the DTG graph (Figure 5B). The maximum weight loss rate in commercial kraft lignin occurred at $325^{\circ} \mathrm{C}$, whereas that of recovered lignin occurred at two different temperatures (232 and $334^{\circ} \mathrm{C}$ ). These results also demonstrated that commercial kraft lignin is more thermally stable than the recovered lignin as a representative of organosolv lignin. This could be because the organosolv fractionation provides a higher number of weak linkages (e.g., $\beta$-O-4) in isolated lignin as compared to kraft lignin (Cherif et al., 2020).

\section{NMR Spectra of Recovered Lignin}

Lignin obtained from the corn stover under the optimal conditions was analyzed using 2DHSQC-NMR. The assignments of correlation signals in the spectra are provided in Supplementary Table S4 based on the correlation signals described in the literature (Jiang et al., 2018). Figures 6, 7 show the 2DHSQC-NMR of recovered lignin and the lignin substructures, respectively. The side-chain region $\left(\delta_{\mathrm{C}} / \delta_{\mathrm{H}}\right.$ 50.0-100.0/2.0-6.0) of recovered lignin is shown in Figure 6A. The data indicated the presence of interunit linkages and terminal structures in lignin and in LCC (lignin-carbohydrate complexes). The most common lignin linkage structures, such as those formed by the substructures of the $\beta$-aryl structures $(\beta-O-4, A)$, resinol $(\beta-\beta, B)$, and phenylcoumaran $(\beta-5, C)$, were evident in the recovered lignin. The most well-known cross-signals represent methoxyl groups (-OMe) and side chains in the $\beta-\mathrm{O}-4$ substructures. The $\mathrm{C}_{\beta}-\mathrm{H}_{\beta}$ correlation signal of the side chain in the $\beta-\mathrm{O}-4$ linkage was attributed to guaiacyl linked with the $p$-hydroxyphenyl units (G/H) (Sun et al., 2011). Added to the interunit lignin linkages was that the strong signals of the LCC linkages from $\mathrm{C}_{2}-\mathrm{H}_{2}\left(\mathrm{X}_{2}\right), \mathrm{C}_{3}-\mathrm{H}_{3}\left(\mathrm{X}_{3}\right), \mathrm{C}_{4}-\mathrm{H}_{4}\left(\mathrm{X}_{4}\right)$, and $\mathrm{C}_{5}-\mathrm{H}_{5}\left(\mathrm{X}_{5}\right)$ were found at $\delta_{\mathrm{C}} / \delta_{\mathrm{H}} 72.69 / 3.05,73.90 / 3.24,75.54 / 3.49,63.25 / 3.15$, and 3.85, respectively (Wen et al., 2012; Fernández-Costas et al., 2014). Furthermore, the signal at $\delta_{\mathrm{C}} / \delta_{\mathrm{H}} 61.43 / 4.17$ corresponding to $\mathrm{C}_{\gamma}-\mathrm{H}_{\gamma}$ in $p$-hydroxycinnamyl alcohol was detected in the recovered lignin. This monolignol is an intermediate in the biosynthesis and may represent the polymeric structures of $p$-coumaryl alcohol or $p$-coumarate ( $p \mathrm{CA})$.

The ${ }^{13} \mathrm{C}-{ }^{1} \mathrm{H}$ correlations $\delta_{\mathrm{C}} / \delta_{\mathrm{H}} 100.0-150.0 / 6.0-8.0$ (Figure 6B) were associated with the aromatic/unsaturated side chain region of the S-, G-, and H- units, and the $p$ CA and FA pendant units corresponded to lignin. The typical $\mathrm{G}$ monolignol structures were determined by various correlation signals of $\mathrm{C}_{2}-\mathrm{H}_{2}\left(\mathrm{G}_{2}\right), \mathrm{C}_{5}-\mathrm{H}_{5}\left(\mathrm{G}_{5}\right)$, and $\mathrm{C}_{6}-\mathrm{H}_{6}$ $\left(\mathrm{G}_{6}\right)$. The $\mathrm{S}$ and $\mathrm{H}$ unit cross-signals were associated with $\mathrm{C}_{2,6}-\mathrm{H}_{2,6}$. The presence of the $\mathrm{C}_{\alpha}$-oxidized $\mathrm{S}$ and $\mathrm{G}$ units referring to $\mathrm{C}_{2,6}-\mathrm{H}_{2,6}$ $\left(\mathrm{S}^{\prime}\right)$ and $\mathrm{C}_{6}-\mathrm{H}_{6}\left(\mathrm{G}^{\prime}\right)$ was detected. The $p C A$ monomers corresponding to the $\mathrm{C}_{2,6}-\mathrm{H}_{2,6}$ and $\mathrm{C}_{3,5}-\mathrm{H}_{3,5}$ correlation peaks were identified; an overlap of the latter signal with the $\mathrm{G}_{5}$ signals from the guaiacyl units in corn stover lignin was observed. The unsaturated $\mathrm{C}_{\alpha}-\mathrm{H}_{\alpha}$ and $\mathrm{C}_{\beta}-\mathrm{H}_{\beta}$ correlations of $p \mathrm{CA}$ were also detected in this region. In addition to the signals of the $p C A$ units, minor signals of ferrulate (FA) were detected. The signal of $\mathrm{C}_{6}-\mathrm{H}_{6}\left(\mathrm{FA}_{6}\right)$ confirmed the existence of these moieties, whereas the signals of unsaturated $\mathrm{C}_{\alpha}-\mathrm{H}_{\alpha}$ and $\mathrm{C}_{\beta}-\mathrm{H}_{\beta}$ correlations overlapped with the signals of the $p \mathrm{CA}$ units. These results showed a high consistency regarding the reported NMR data for the $p C A$ units and were confirmed using Py-GC/MS (Kim et al., 2017). 

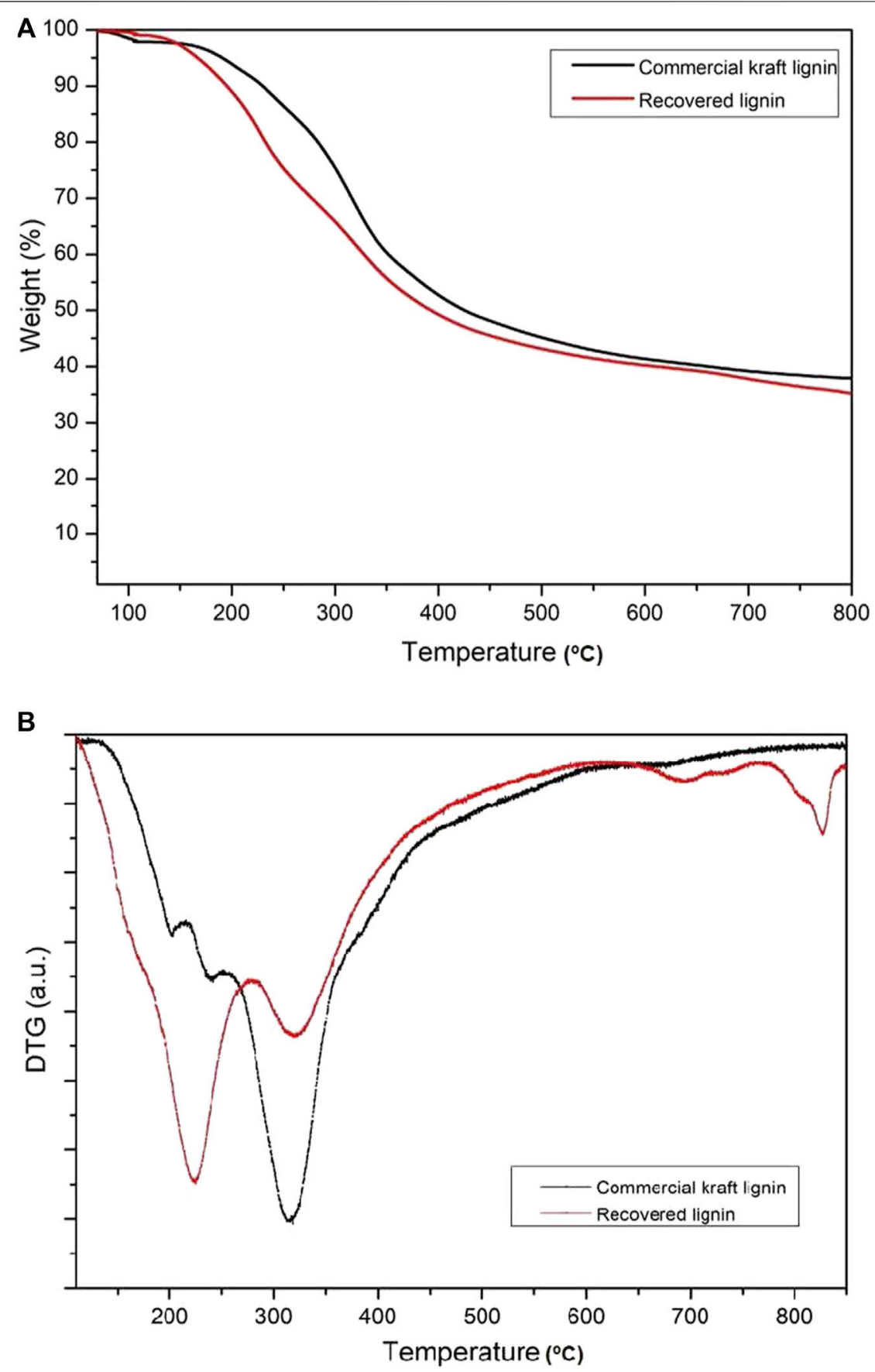

FIGURE 5 | (A) TG (weight loss) and (B) DTG (derivatives of weight loss) curves of commercial kraft lignin and recovered lignin after solvothermal fractionation.

\section{Identification of Composition of Commercial Kraft Lignin and Recovered} Lignin

The Py-GC/MS analysis indicated more substantial variations in the lignin composition of lignin recovered under optimal conditions compared to that of commercial kraft lignin. The identities and relative abundance of the released lignin-derived phenolic compounds and relative abundance of the $\mathrm{H}, \mathrm{G}$, and S-lignin units and $\mathrm{S} / \mathrm{G}$ ratios are illustrated in Supplementary Table S5. The results showed that the commercial kraft lignin contained G-units (90.4\%) almost exclusively, with a minor number of $\mathrm{H}$-units (9.6\%), whereas the recovered lignin had a higher amount of G- (53.5\%) than S- (33.1\%) units, leading to an S/G ratio of approximately 0.7 . 


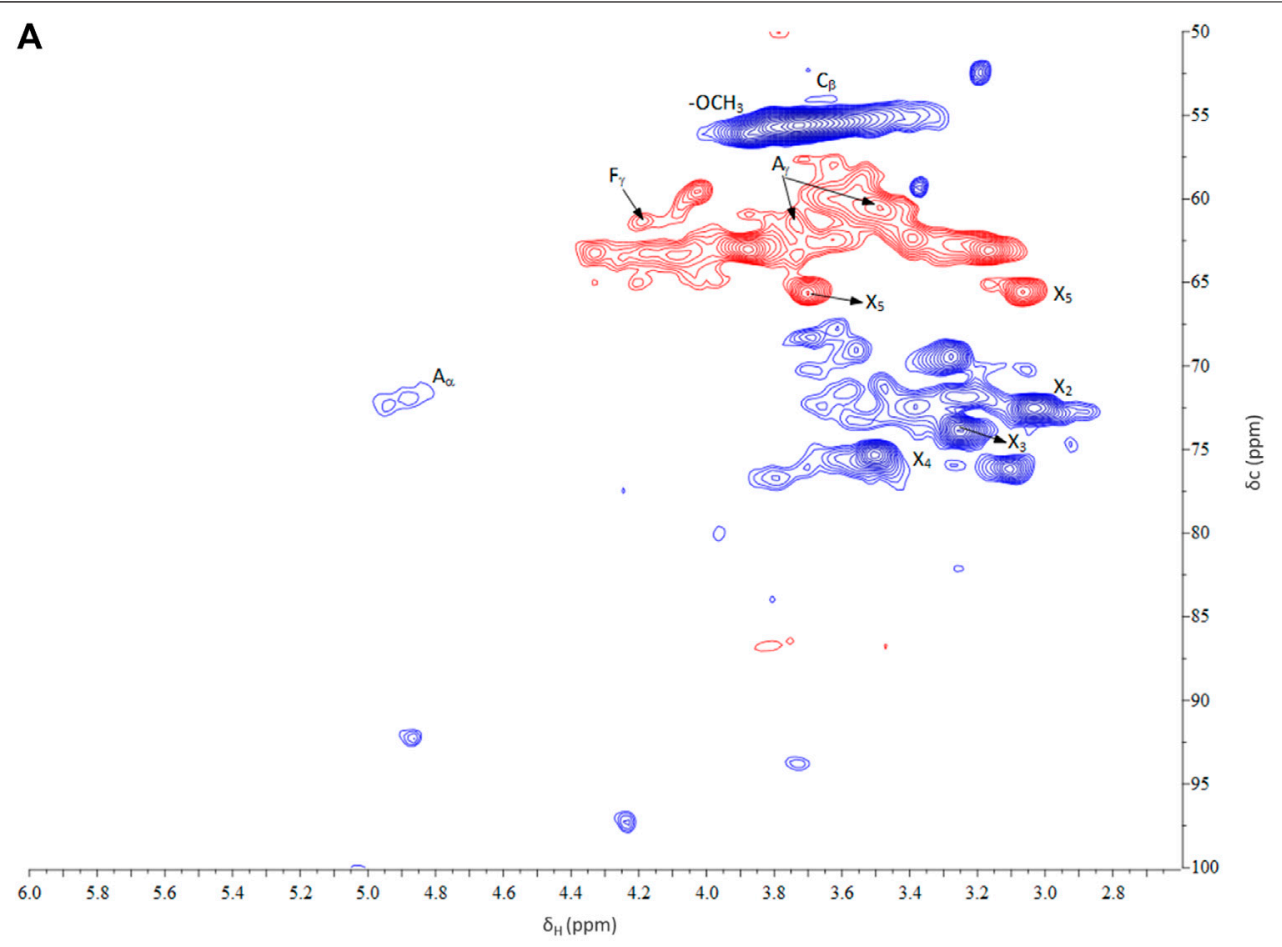

B

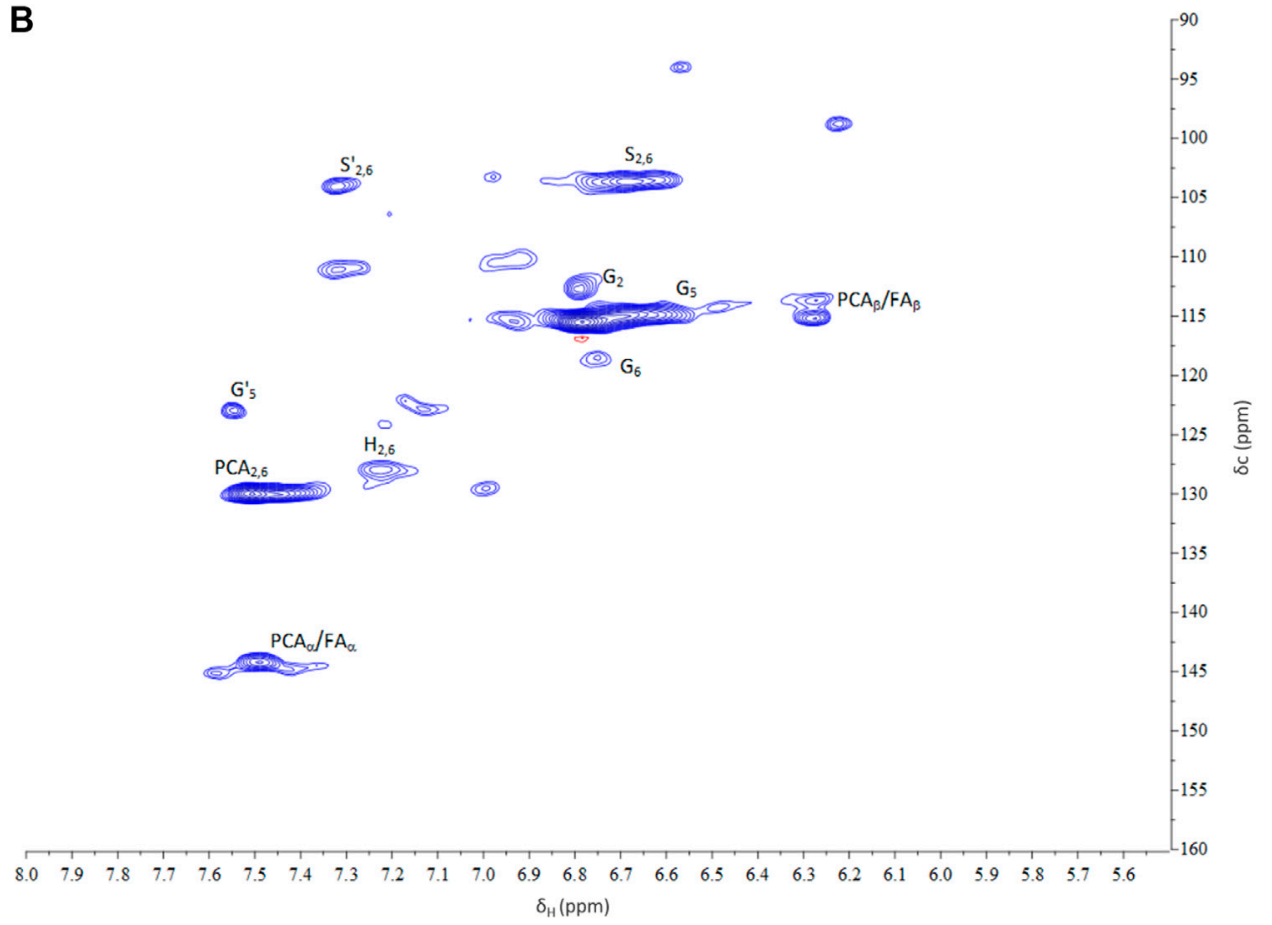

FIGURE 6 | 2DHSQC-NMR spectra of (A) side-chain and (B) aromatic regions of recovered lignin.

Higher amounts of 4-vinylguaiacol (14.8\%) and 4-vinylphenol (2.5\%) were released from the recovered lignin sample compared with the commercial kraft lignin; these elements accounted for the high percentage of the G- and H-type units found in these samples.
Nonetheless, notably, 4-vinylguaiacol, and 4-vinylphenol may also have occurred from FA and $p$-coumarates $(p \mathrm{CA})$, respectively upon decarboxylation during pyrolysis as usually arises during the pyrolysis of grass lignins (Del Río et al., 2012; Del Río et al., 


\section{Lignin substructure}

A<smiles>CCOc1c(C)cc(C(O)C(CO)Oc2c(C)cc(C)cc2C)cc1OC</smiles>

B<smiles>CC=CC1OCC2C(c3cc(C)c(OC)c(OC)c3)OCC12</smiles><smiles>CCOc1c(C)cc(C2Oc3c(OC)cc([N+](=O)[O-])cc3C2Cc2ccccc2)cc1OC</smiles>

D<smiles>CCOc1c(OC)cc(C(C)O)cc1OC</smiles>

H<smiles>CCOc1ccc(C(C)O)cc1</smiles>

E<smiles>CCOc1c(OC)cc(C(C)=O)cc1OC</smiles>

I<smiles>CCOC(=O)/C=C/c1ccc(O)cc1</smiles>

$\mathbf{F}$<smiles>CCOc1c(C)cc(C(C)O)cc1OC</smiles>

$J$<smiles>CCOC(=O)/C=C/c1ccc(OCC)c(OC)c1</smiles>

G<smiles>CCOc1c(C)cc(C(C)=O)cc1OC</smiles>

K<smiles>OC/C=C/c1ccc(O)cc1</smiles>

FIGURE 7 | Lignin substructures detected in the HSQC spectra of recovered lignin samples: (A) $\beta$-O-4 linkages; (B) resinol structures formed by $\beta$ - $\beta$; (C) phenylcoumaran substructures formed by $\beta-5$; (D) syringyl unit; (E) oxidized syringyl unit bearing a carbonyl group at C $\alpha$ (phenolic); (F) guaiacyl unit; (G) oxidized guaiacyl unit bearing a carbonyl group at $\mathrm{Ca}$ (phenolic); (H) p-hydroxyphenyl unit; (I) p-coumarate; (J) ferrulate; and (K) p-hydroxycinnamyl alcohol.

2015; Del Río et al., 2017). Remarkably, these lignin samples released high amounts of $\mathrm{C}_{\alpha}$-oxidized phenolic compounds derived from the H-, G-, and S-lignin units, including aromatic aldehydes (3,4dimethoxybenzaldehyde, vanillin, and syringaldehyde) and ketones (acetoisovanillone, acetosyringone, guaiacylacetone, and andpropiosyringone). Considerable amounts of $\mathrm{C}_{\alpha}$-oxidized compounds released from the recovered lignin clearly indicated the high extent of oxidation compared with the commercial kraft lignin.

Interestingly, a series of fatty acids (FatAc), such as hexadecenoic acid, 6-octadecenoic acid, 1-heptadecanecarboxylic acid, octadecanoic acid, ethyl ester, docosanoic acid, ethyl ester, and n-hexadecanoic acid, accounted for $10.9 \%$ of all released compounds that emerged during pyrolysis, indicating the high aliphatic character of the recovered lignin sample. Nevertheless, no additional structural information was obtained using Py-GC/MS from the sample due to the technique's current limitations, such as decarboxylation of the carboxylic moieties (Jose et al., 1998; Ana et al., 1998).

Linkages between the lignin units, (such as $\beta-\mathrm{O}-4 / \alpha-\mathrm{O}-4$ ) were cleaved corresponding to a range in temperature $\left(150-350^{\circ} \mathrm{C}\right)$ because of the relatively low bond dissociation energy to 
produce the alkoxyls of the G-type substructures and the hydroxyl groups of the H-type substructures as the major products.

\section{CONCLUSION}

A modified one-step organosolv fractionation method of lignin fractionation from corn stover was investigated. Under the optimum conditions, the method enhanced lignin removal (75.0\%) from the solid phase and recovered lignin in the organic phase (72.9\%). The fractionation process provides highly pure recovered lignin (89.6\%) under the optimal conditions. An FTIR analysis showed variations in the bonding pattern and functional groups. These distinguishable chemical functionalities are substantial components for lignin product applications. The thermal degradation of the recovered lignin was due to the breakdown of the interunit links and breakage of various bonds of the lignin structure's weak internal linkages. GPC analysis recorded a low molecular weight for the recovered lignin containing high levels of phenolic hydroxyls, methoxyl function groups, and $\beta-\mathrm{O}-4 / \alpha-\mathrm{O}-4$ linkages. The Py/GCMS analysis illustrated the predominance of G- (53.5\%) units over S- (33.1\%) units. A series of fatty acids was obtained during pyrolysis. This work demonstrates a novel solvothermal-based lignin fractionation of lignocellulosic biopolymers with improved reaction efficiency and selectivity for potential application in an integrated biorefinery.

\section{REFERENCES}

Abdelkhalik, A., Elsayed, H., Hassan, M., Nour, M., Shehata, A. B., and Helmy, M. (2018). Using thermal Analysis Techniques for Identifying the Flash point Temperatures of Some Lubricant and Base Oils. Egypt. J. Pet. 27 (1), 131-136. doi:10.1016/j.ejpe.2017.02.006

Ahorsu, R., Medina, F., and Constantí, M. (2018). Significance and Challenges of Biomass as a Suitable Feedstock for Bioenergy and Biochemical Production: A Review. Energies 11 (12), 3366-66. doi:10.3390/en11123366

Balan, V., Mihai, C.-T., Cojocaru, F.-D., Uritu, C.-M., Dodi, G., Botezat, D., et al. (2019). Vibrational Spectroscopy Fingerprinting in Medicine: from Molecular to Clinical Practice. Materials 12 (18), 2884. doi:10.3390/ ma12182884

Buranov, A. U., and Mazza, G. (2008). Lignin in Straw of Herbaceous Crops. Ind. Crops Prod. 28 (3), 237-259. doi:10.1016/j.indcrop.2008.03.008

Bykov, I. (2008). Characterization of Natural and Technicallignin Using FTIR Spactroscopy. Luleå: chemical technology department of chemical engineerinf and deosciences division of chemical technology. Bibliographically approved, 1402-1552.

Chutikan, I., Marisa, R., Verawat, C., and Navadol, L. (2018). Characteristics of Lignin Extracted from Different Lignocellulosic Materials via Organosolv Fractionation. Bioenergy Res. 11, 277-290. doi:10.1007/s12155-018-9895-2

del Río, J. C., Lino, A. G., Colodette, J. L., Lima, C. F., Gutiérrez, A., Martínez, Á. T., et al. (2015). Differences in the Chemical Structure of the Lignins from Sugarcane Bagasse and Straw. Biomass and Bioenergy 81, 322-338. doi:10.1016/j.biombioe.2015.07.006

del Río, J. C., Rencoret, J., Prinsen, P., Martínez, Á. T., Ralph, J., and Gutiérrez, A. (2012). Structural Characterization of Wheat Straw Lignin as Revealed by Analytical Pyrolysis, 2D-NMR, and Reductive Cleavage Methods. J. Agric. Food Chem. 60, 5922-5935. doi:10.1021/jf301002n

Del Río, J., Gutiérrez, A., Rodríguez, I., Ibarra, D., and Martinez, A. T. (2017). Composition of Non-woody Plant Lignins and Cinnamic Acids by Py-GC/MS, Py/TMAH and FTIR. J. Anal. Appl. Pyrolysis. 79, 39-46. doi:10.1016/j.jaap.2006.09.003

\section{DATA AVAILABILITY STATEMENT}

The original contributions presented in the study are included in the article/Supplementary Material, further inquiries can be directed to the corresponding author.

\section{AUTHOR CONTRIBUTIONS}

All authors listed have made a substantial, direct, and intellectual contribution to the work and have approved it for publication.

\section{FUNDING}

This project was financially supported by a research grant (RTA 6280003) from the Thailand Research Fund. SI and NS were supported by a Unit of Excellence (UOE64001) from the University of Phayao.

\section{SUPPLEMENTARY MATERIAL}

The Supplementary Material for this article can be found online at: https://www.frontiersin.org/articles/10.3389/fchem.2021.697237/ full\#supplementary-material

Domínguez-Robles, J., Sánchez, R., Espinosa, E., Savy, D., Mazzei, P., Piccolo, A., et al. (2017). Isolation and Characterization of Gramineae and Fabaceae Soda Lignins. Int. J. Mol. Sci. 18 (2), 327. doi:10.3390/ijms18020327

Fernández-Costas, C., Gouveia, S., Sanromán, M. A., and Moldes, D. (2014). Structural Characterization of Kraft Lignins from Different Spent Cooking Liquors by $1 \mathrm{D}$ and 2D Nuclear Magnetic Resonance Spectroscopy. Biomass and Bioenergy 63, 156-166. doi:10.1016/j.biombioe.2014.02.020

Fodil Cherif, M., Trache, D., Brosse, N., Benaliouche, F., and Tarchoun, A. F. (2020). Comparison of the Physicochemical Properties and Thermal Stability of Organosolv and Kraft Lignins from Hardwood and Softwood Biomass for Their Potential Valorization. Waste Biomass Valor. 11, 6541-6553. doi:10.1007/s12649-020-00955-0

Gao, S., Zhao, J., Wang, X., Guo, Y., Han, Y., and Zhou, J. (2018). Lignin Structure and Solvent Effects on the Selective Removal of Condensed Units and Enrichment of S-type Lignin. Polymers 10 (9), 967. doi:10.3390/polym10090967

Gonultas, O., and Candan, Z. (2018). Chemical Characterization and Ftir Spectroscopy of Thermally Compressed eucalyptus wood Panels. Maderas: Cienc. Tecnol. 20 (3), 431-442. doi:10.4067/S0718-221X2018005031301

Hyväkkö, U., Maltari, R., Kakko, T., Kontro, J., Mikkilä, J., Kilpeläinen, P., et al. (2020). On the Effect of Hot-Water Pretreatment in Sulfur-free Pulping of Aspen and Wheat Straw. ACS Omega 5 (1), 265-273. doi:10.1021/acsomega.9b02619

Imman, S., Arnthong, J., Burapatana, V., Champreda, V., and Laosiripojana, N. (2015). Fractionation of rice Straw by a Single-step Solvothermal Process: Effects of Solvents, Acid Promoters, and Microwave Treatment. Renew. Energ. 83, 663-673. doi:10.1016/j.renene.2015.04.062

Javad, S., Sally, K., Derval dos Santos, R., Alcides, L., and Sain., Mohini. (2014). Thermal Characteristics of Lignin Residue from Industrial Processes. BioResources 9 (1), 725-737. doi:10.15376/biores.9.1.725-737

Jiang, B., Zhang, Y., Guo, T., Zhao, H., and Jin, Y. (2018). Structural Characterization of Lignin and Lignin-Carbohydrate Complex (LCC) from Ginkgo Shells (Ginkgo Biloba L.) by Comprehensive NMR Spectroscopy. Polymers 10 (7), 736. doi:10.3390/polym10070736

Jiang, X., Savithri, D., Du, X., Pawar, S., Jameel, H., Chang, H.-m., et al. (2016). Fractionation and Characterization of Kraft Lignin by Sequential Precipitation 
with Various Organic Solvents. ACS Sustain. Chem. Eng. 5 (1), 835-842. doi:10.1021/acssuschemeng.6b02174

Jose, C., del R'10, A. G., Francisco, J., Gonza'lez, V., Francisco, M., and Romero., Javier. (1998). Characterization of Organic Deposits Produced in the Kraft Pulping of Eucalyptus Globulus wood. J. Chromatogr. A. 823, 457-465. doi:10.1016/S0021-9673(98)00179-4

Kawamoto, H. (2017). Lignin Pyrolysis Reactions. J. Wood Sci. 63 (2), 117-132. doi:10.1007/s10086-016-1606-z

Kim, D. (2018). Physico-Chemical Conversion of Lignocellulose: Inhibitor Effects and Detoxification Strategies: A Mini Review. Molecules 23 (2), 309. doi:10.3390/molecules23020309

Kim, H., Padmakshan, D., Li, Y., Rencoret, J., Hatfield, R. D., and Ralph, J. (2017). Characterization and Elimination of Undesirable Protein Residues in Plant Cell Wall Materials for Enhancing Lignin Analysis by Solution-State Nuclear Magnetic Resonance Spectroscopy. Biomacromolecules 18 (12), 4184-4195. doi:10.1021/acs.biomac.7b01223

Klein, S. E., Rumpf, J., Kusch, P., Albach, R., Rehahn, M., Witzleben, S., et al. (2018). Unmodified Kraft Lignin Isolated at Room Temperature from Aqueous Solution for Preparation of Highly Flexible Transparent Polyurethane Coatings. RSC Adv. 8 (71), 40765-40777. doi:10.1039/c8ra08579j

Kupczyk, A., Mączyńska, J., Redlarski, G., Tucki, K., Bączyk, A., and Rutkowski, D. (2019). Selected Aspects of Biofuels Market and the Electromobility Development in Poland: Current Trends and Forecasting Changes. Appl. Sci. 9 (2), 254. doi:10.3390/app9020254

Li, J., Zhang, J., Zhang, S., Gao, Q., Li, J., and Zhang, W. (2018). Alkali Lignin Depolymerization under Eco-Friendly and Cost-Effective $\mathrm{NaOH}$ /urea Aqueous Solution for Fast Curing Bio-Based Phenolic Resin. Ind. Crops Prod. 120, 25-33. doi:10.1016/j.indcrop.2018.04.027

Liu, X., Jiang, Z., Feng, S., Zhang, H., Li, J., and Hu, C. (2019). Catalytic Depolymerization of Organosolv Lignin to Phenolic Monomers and Low Molecular Weight Oligomers. Fuel 244, 247-257. doi:10.1016/j.fuel.2019.01.117

Mathew, A. K., Abraham, A., Mallapureddy, K. K., and Sukumaran, R. K. (2018). Lignocellulosic Biorefinery Wastes, or Resources. Waste Biorefin., 267-297. doi:10.1016/B978-0-444-63992-9.00009-4

More, S. (2019). Chapter 2 - Structure and Characteristics of Lignin. Amsterdam: Lignin Bioinorganic Chemistry and Applications, 25-46.

Nopparat, S., Natthakorn, K., Wikanda, T., and Navadol, L. (2018). Fractionation of Lignocellulosic Biopolymers from Sugarcane Bagasse Using Formic Acid Catalyzed Organosolv Process. 3 Biotech. 8 (5), 8-221. doi:10.1007/s13205-018-1244-9

Oliveira, L., Evtuguin, D., Cordeiro, N., and Silvestre, A. J. D. (2009). Structural Characterization of Stalk Lignin from Banana Plant. Ind. Crops Prod. 29 (1), 86-95. doi:10.1016/j.indcrop.2008.04.012

Ouyang, X., Huang, X., Hendriks, B. M. S., Boot, M. D., and Hensen, E. J. M. (2018). Coupling Organosolv Fractionation and Reductive Depolymerization of Woody Biomass in a Two-step Catalytic Process. Green. Chem. 20, 2308-2319. doi:10.1039/c8gc00639c

Park, Y., Kim, J., and Kim, T. (2018). Pretreatment of Corn Stover Using Organosolv with Hydrogen Peroxide for Effective Enzymatic Saccharification. Energies 11 (5), 1301. doi:10.3390/en11051301

Perera, F. (2017). Pollution from Fossil-Fuel Combustion Is the Leading Environmental Threat to Global Pediatric Health and Equity: Solutions Exist. I. J. Environ. Public. Health. 15 (1), 16-17. doi:10.3390/ijerph15010016

Quoc Lam, H., Le Bigot, Y., Delmas, M., and Avignon, G. (2001). A New Procedure for the Destructuring of Vegetable Matter at Atmospheric Pressure by a Catalyst/solvent System of Formic Acid/acetic acid.Applied to the Pulping of Triticale Straw. Ind. Crops Prod. 14, 139-144. doi:10.1016/S0926-6690(01)00077-2

Raspolli Galletti, A. M., D’Alessio, A., Licursi, D., Antonetti, C., Valentini, G., Galia, A., et al. (2015). Midinfrared FT-IR as a Tool for Monitoring Herbaceous Biomass Composition and its Conversion to Furfural. J. Spectrosc. 2015, 1-12. doi:10.1155/2015/719042

Sakamoto, Y., Imamura, K., and Onda, A. (2020). Hydrolysis of Oligosaccharides and Polysaccharides on Sulfonated Solid Acid Catalysts: Relations between Adsorption Properties and Catalytic Activities. ACS Omega, 5 (38), 24964-24972. doi:10.1021/acsomega.0c03932

Satari, B., Karimi, K., and Kumar, R. (2019). Cellulose Solvent-Based Pretreatment for Enhanced Second-Generation Biofuel Production: a Review. Sustain. Energ. Fuels 3 (1), 11-62. doi:10.1039/C8SE00287H

Schutyser, W., Renders, T., Van den Bosch, S., Koelewijn, S.-F., Beckham, G. T., and Sels, B. F. (2018). Chemicals from Lignin: an Interplay of Lignocellulose
Fractionation, Depolymerisation, and Upgrading. Chem. Soc. Rev. 47 (3), 852-908. doi:10.1039/C7CS00566K

Seca, A. M., Cavaleiro, J. A., Domingues, F. M., Silvestre, A. J., Evtuguin, D., and Neto, C. P. (2000). Structural Characterization of the Lignin from the Nodes and Internodes of Arundo donax Reed. J. Agric. Food Chem. 48, 817-824. doi:10.1021/jf9910988

Sluiter, A., Hames, B., Ruiz, R., Scarlata, C., Sluiter, J., Templeton, D., et al. (2008). Determination of Structural Carbohydrates and Lignin in Biomass-Nrel/tp510-42618. Colorado: Laboratory Analytical Procedure.

Sun, X.-F., Jing, Z., Fowler, P., Wu, Y., and Rajaratnam, M. (2011). Structural Characterization and Isolation of Lignin and Hemicelluloses from Barley Straw. Ind. Crops Prod. 33 (3), 588-598. doi:10.1016/j.indcrop.2010.12.005

Suriyachai, N., Champreda, V., Sakdaronnarong, C., Shotipruk, A., and Laosiripojana, N. (2017). Sequential Organosolv Fractionation/hydrolysis of Sugarcane Bagasse: The Coupling Use of Heterogeneous H3PO4-Activated Carbon as Acid Promoter and Hydrolysis Catalyst. Renew. Energ. 113, 1141-1148. doi:10.1016/j.renene.2017.06.003

Wanmolee, W., Beltramini, J. N., Bartley, J., Laosiripojana, N., and Doherty, W. O. S. (2021). One Step Liquefaction of Hardwood Lignin to Oligomers Soluble in Polymerizable Solvents. Ind. Crops Prod., 162, 113259. doi:10.1016/ j.indcrop.2021.113259

Wanmolee, W., Laosiripojana, N., Daorattanachai, P., Moghaddam, L., Rencoret, J., del Río, J. C., et al. (2018). Catalytic Conversion of Organosolv Lignins to Phenolic Monomers in Different Organic Solvents and Effect of Operating Conditions on Yield with Methyl Isobutyl Ketone. ACS Sustain. Chem. Eng. 6(3), 3010-3018. doi:10.1021/acssuschemeng.7b02721

Wen, J.-L., Xue, B.-L., Xu, F., and Sun, R.-C. (2012). Unveiling the Structural Heterogeneity of Bamboo Lignin by In Situ HSQC NMR Technique. Bioenerg. Res. 5 (4), 886-903. doi:10.1007/s12155-012-9203-5

Xianzhi, M., Samarthya, B., Yang, Z., Yunqiao, P., John, R. D., Li, S., et al. (2020). Effects of the Advanced Organosolv Pretreatment Strategies on Structural Properties of Woody Biomass. Ind. Crops Prod. 146, 112-144. doi:10.1016/ j.indcrop.2020.112144

Yedro, F. M., García-Serna, J., Cantero, D. A., Sobrón, F., and Cocero, M. J. (2015). Hydrothermal Fractionation of Grape Seeds in Subcritical Water to Produce Oil Extract, Sugars and Lignin. Catal. Today 257, 160-168. doi:10.1016/ j.cattod.2014.07.053

Zhan, S., Chenguang, W., Chenguang, W., Kang, B., Xinghua, Z., Chiling, Y., et al. (2017). Py-GC/MS Study of Lignin Pyrolysis and Effect of Catalysts on Product Distribution. Int. J. Agric. Biol. Eng. 10 (5), 214-225. doi:10.25165/j.ijabe.20171005.2852

Zhang, C., and Wang, F. (2020). Catalytic Lignin Depolymerization to Aromatic Chemicals. Acc. Chem. Res. 53, 470-484. doi:10.1021/acs.accounts.9b00573

Zhang, R., Maltari, R., Guo, M., Kontro, J., Eronen, A., and Repo, T. (2020). Facile Synthesis of Vanillin from Fractionated Kraft Lignin. Ind. Crops Prod. 145, 112-209. doi:10.1016/j.indcrop.2020.112095

Zhang, Y., Huo, F., Wang, Y., Xia, Y., Tan, X., Zhang, S., et al. (2019). Theoretical Elucidation of $\beta-\mathrm{O}-4$ Bond Cleavage of Lignin Model Compound Promoted by Sulfonic Acid-Functionalized Ionic Liquid. Front. Chem. 7, 78. doi:10.3389/ fchem.2019.00078

Conflict of Interest: The authors declare that the research was conducted in the absence of any commercial or financial relationships that could be construed as a potential conflict of interest.

Publisher's Note: All claims expressed in this article are solely those of the authors and do not necessarily represent those of their affiliated organizations, or those of the publisher, the editors and the reviewers. Any product that may be evaluated in this article, or claim that may be made by its manufacturer, is not guaranteed or endorsed by the publisher.

Copyright () 2021 Khongchamnan, Wanmolee, Laosiripojana, Champreda, Suriyachai, Kreetachat, Sakulthaew, Chokejaroenrat and Imman. This is an open-access article distributed under the terms of the Creative Commons Attribution License (CC BY). The use, distribution or reproduction in other forums is permitted, provided the original author(s) and the copyright owner(s) are credited and that the original publication in this journal is cited, in accordance with accepted academic practice. No use, distribution or reproduction is permitted which does not comply with these terms. 